\title{
10. TERTIARY AND QUATERNARY SILICOFLAGELLATES, ACTINISCIDIANS, AND EBRIDIANS FROM THE EASTERN PACIFIC OFF PERU (LEG 112)1
}

\author{
Erlend Martini²
}

\begin{abstract}
Neogene and Quaternary silicoflagellates, actiniscidians, and ebridians are described from Sites 679 through 688 in the eastern Pacific off Peru. Five silicoflagellate zones and one horizon can be distinguished in the Neogene and Quaternary sequences. The encountered Eocene and Oligocene sequences are barren in silicoflagellates. Several hiatuses were noted in the Neogene and early Pleistocene sequences. Displaced silicoflagellates and ebridians from older strata were found occasionally, with a distinct increase in the Quaternary at Site 688. Distribution lists for species found are presented for Sites $682,683,685$ and 688 . Systematic discussion centers on the Distephanus bioctonarius group, with special reference to Hole 681A. Two new forms (Distephanus bioctonarius $\mathrm{f}$. decimarius and Distephanus speculum subsp. speculum f. pseudoseptenarius) are described from the eastern Pacific Quaternary sequence.
\end{abstract}

\section{INTRODUCTION}

During Leg 112 of the Ocean Drilling Program (ODP) 10 sites (679 through 688) were occupied, and 27 holes were drilled in the forearc basins and the continental slope of the convergent margin off Peru (Fig. 1). The main objectives of Leg 112 were (1) to investigate the paleoceanographic conditions of the upper-slope basin deposits in connection with fluctuations of the upwelling system, (2) to reconstruct the vertical movement of the continental margin, (3) to study the nature and age of the transition zone that lies between the lower-slope accretionary complex and the metamorphic basement, and (4) to evaluate the geochemical processes connected with the upwelling system and diagenesis in organiccarbon-rich sediments. Most sites were aligned along two transects at $9^{\circ} \mathrm{S}$ (Sites 684,683 , and 685 ) and near $11^{\circ} \mathrm{S}$ (Sites $681,680,679,688$, and 682). Two additional sites were occupied in the Pisco Basin (Sites 686 and 687).

All holes yielded silicoflagellates, although some barren intervals were noted in the late Miocene to Holocene sequences in the upwelling areas. Paleogene sediments did not contain silicoflagellates or other siliceous fossils; these sediments were recovered only in the deeper Sites 682,683 , and 688 (Fig. 1). The silicoflagellate assemblages found at Sites 679 through 688 are discussed later, and fossil lists for selected samples for Sites $682,683,685$, and 688 are presented in Tables 1 to 4 . Actiniscidians and ebridians found during the silicoflagellate study were listed and are discussed for each site. Their distribution in selected samples from Sites 682, 683, and 685 is shown in Tables 1 through 3.

Frequencies are based on specimens found in three traverses, each $40 \mathrm{~mm}$ long, across routine smear slides viewed with a $12.5 \mathrm{X}$ ocular and a $25 \mathrm{X}$ objective: rare $=1-4$ specimens, few $=5-14$ specimens, common $=15-50$ specimens, abundant $=>50$ specimens.

\footnotetext{
${ }^{1}$ Suess, E., von Huene, R., et al. 1990 Proc. ODP, Sci. Results, 112: College Station, TX (Ocean Drilling Program).

${ }^{2}$ Geologisch-Paläontologisches Institut der Universität, Senckenberg-Anlage 32-34, D-6000 Frankfurt am Main, Federal Republic of Germany.
}

\section{SILICOFLAGELLATE ZONATION}

As outlined in Locker and Martini (1986a), a uniform silicoflagellate zonation from the middle Miocene onward is hampered by the distinct differentiation of assemblages between several regions of the oceans, whereas in the early Miocene and Paleogene silicoflagellate assemblages seem to be more uniform in all oceans. Therefore, a combination of silicoflagellate zones used during DSDP Leg 7 (Equatorial Pacific, Martini, 1971), Leg 33 (Central Pacific, Martini, 1976), and Leg 90 (Southwest Pacific, Locker and Martini, 1986a), with updated names for some silicoflagellate taxa, was used during Leg 112 off Peru (Fig. 2).

Five silicoflagellate zones and one horizon can be distinguished in the middle Miocene to Holocene interval. The early Miocene interval, which was encountered in Holes 682A and $688 \mathrm{E}$, has a relatively low content of siliceous fossils. Because of low recovery and the rare occurrence of silicoflagellates, a detailed zonation was not possible. However, the presence of some Naviculopsis species and of the diatom Rocella gelida is indicative of this interval, which was termed Naviculopsis Assemblage (Fig. 2).

Together with the datum indicators some first $(\mathrm{F})$ or last $(\mathrm{L})$ occurrences of additional species are shown in Figure 2, which were found occasionally but could not be used for further subdivision because of their scattered occurrence in the investigated region. In addition, the presence of Dictyocha perlaevis delicata at Site 688 , which was taken as zonal indicator for the Dictyocha perlaevis delicata Zone in Bukry (1976, Leg 34) or Distephanus aculeatus f. aculeatus (syn. Distephanus boliviensis) in some other cases, helped to identify the position of cores within the relatively broad silicoflagellate zonation.

\section{Naviculopsis Assemblage}

Definition. Interval below the last occurrence of Naviculopsis species especially Naviculopsis quadratum.

Occurrence. Found at Sites 682 and 688.

Remarks. This early Miocene interval is represented elsewhere by the Naviculopsis navicula Zone and part of the Naviculopsis lata Zone (Martini and Müller, 1976) or the Naviculopsis iberica Zone (Locker and Martini, 1986a). An additional marker in the lower part is the diatom Rocella gelida (Barron, 1985). 


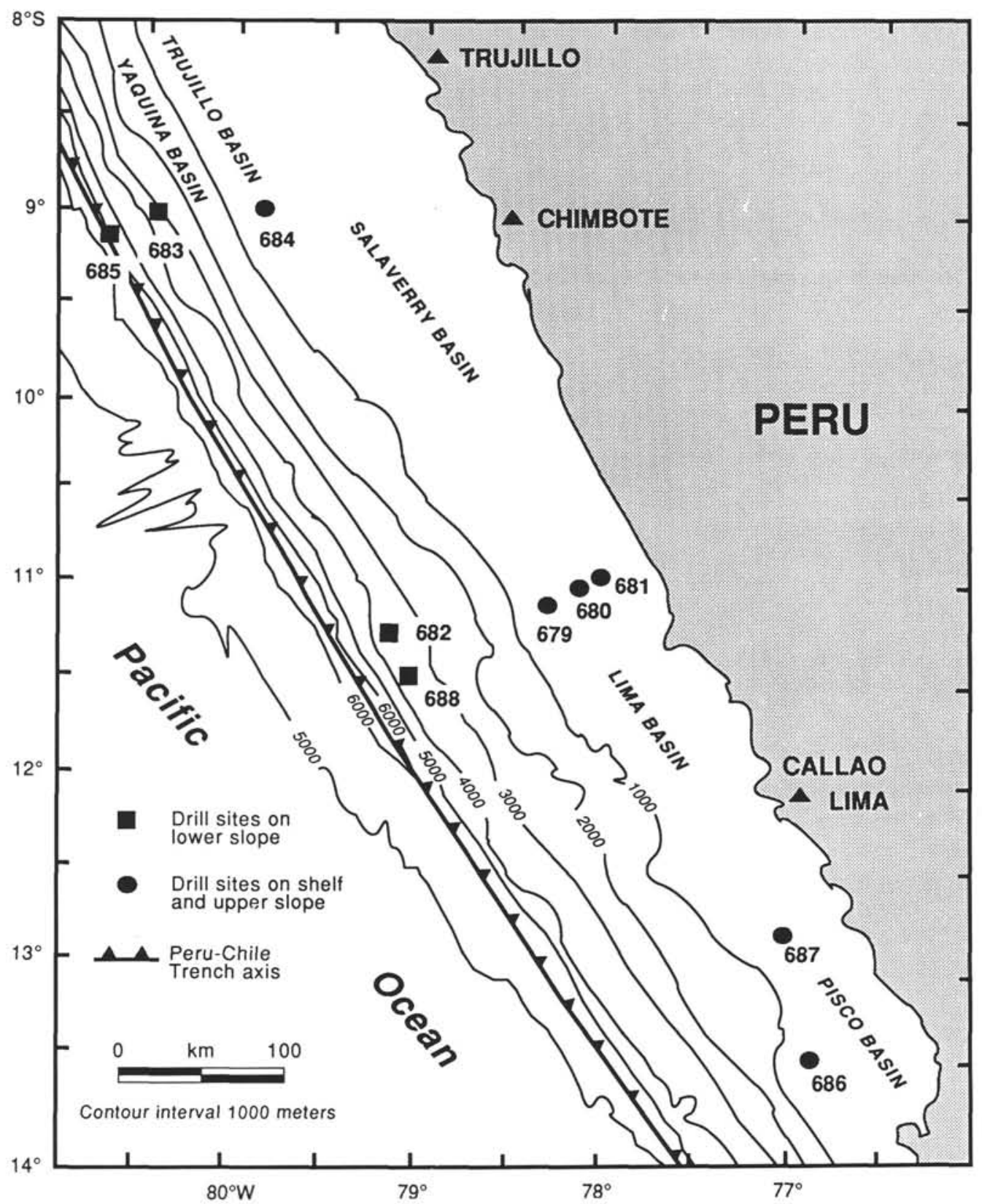

Figure 1. Location of sites drilled during Leg 112 in the eastern South Pacific off Peru.

\section{Corbisema triacantha Zone}

Definition. Interval from the last occurrence of Naviculopsis quadratum to the last occurrence of Corbisema triacantha (Martini, 1971, 1972). Lower to middle Miocene.

Occurrence. Found at Sites 682 and 688.

Remarks. Since the silicoflagellate assemblage in the lower Miocene is rather meager, the last occurrence of Naviculopsis species was used to evaluate the base of the Corbisema triacantha Zone at both sites. This zone contains the Distephanus stauracanthus Horizon in the upper part above the first occurrence of Mesocena diodon, which was used to subdivide the $C$. triacantha Zone into a lower and an upper part by Locker and Martini (in press).

\section{Distephanus stauracanthus Horizon}

Definition. Interval from the first to the last occurrence of Distephanus stauracanthus (Martini, 1971). Middle Miocene.
Occurrence. Found at Sites 682, 683 and 688.

Remarks. Commonly D. stauracanthus f. stauracanthus is associated with D. stauracanthus f. octagonus. However, at Site 682 the latter was observed in Samples 112-682A-21X-CC and $-22 \mathrm{X}-\mathrm{CC}$, well above the D. stauracanthus Horizon in Core 112-682A-31X and the last occurrence of Corbisema triacantha. A similar case was noted at Site 66 (Martini, 1971, Equatorial Pacific).

\section{Dictyocha varia Zone}

Definition. Interval from the last occurrence of Corbisema triacantha to the first occurrence of Dictyocha messanensis stapedia (Locker and Martini, 1986a, top changed). Middle to upper Miocene. 688.

Occurrence. Encountered at Sites 679, 682, 683, 685 and

Remarks. Since Paramesocena circulus apiculata is too rare in the samples off Peru, the first occurrence of Dictyocha 
Table 1. Distribution of silicoflagellates, actiniscidians, and ebridians in selected samples from Hole $682 \mathrm{~A}$ and indication of silicoflagellate zones.

\begin{tabular}{|c|c|c|c|c|c|c|c|c|c|c|c|c|c|c|c|c|c|c|c|c|c|c|c|c|}
\hline & 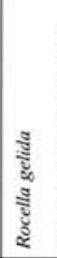 & $\begin{array}{l}\text { हू } \\
\text { हूँ } \\
\text { है } \\
\text { है } \\
\text { हैँ } \\
\text { है }\end{array}$ & 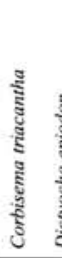 & 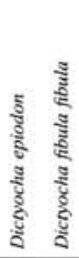 & 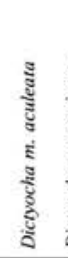 & 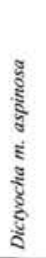 & 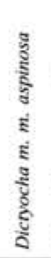 & 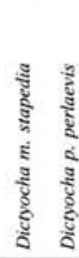 & 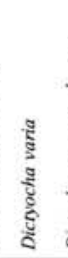 & 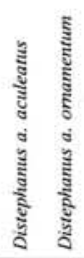 & $\begin{array}{l}\text { हैँ } \\
\text { हैँ } \\
\text { है } \\
\text { है } \\
\text { हैँ } \\
\text { हैँ }\end{array}$ & 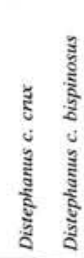 & 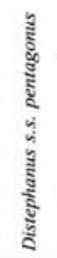 & 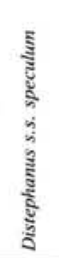 & 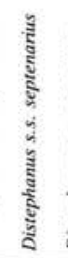 & 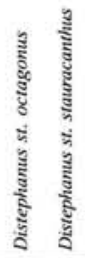 & 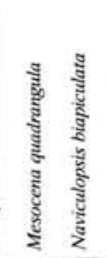 & 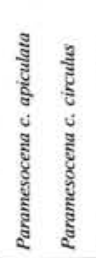 & $\begin{array}{l}\text { हूँ } \\
\text { हूँ } \\
\text { है } \\
\text { है } \\
\text { है } \\
\text { है } \\
\text { है }\end{array}$ & $\begin{array}{l}\text { हैँ } \\
\text { हैँ } \\
\text { हूँ } \\
\text { हूँ } \\
\text { हू }\end{array}$ & 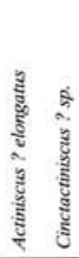 & 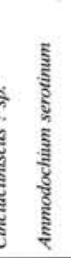 & 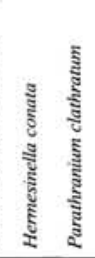 & 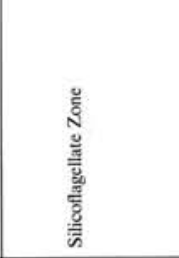 \\
\hline $\begin{array}{l}1 \mathrm{H}, \mathrm{cc} \\
2 \mathrm{H}, \mathrm{cc}\end{array}$ & & & & & R & & $\begin{array}{l}\mathrm{R} \\
\mathrm{F}\end{array}$ & $\mathbf{R}$ & & $\bullet$ & $\mathbf{R}$ & & $\mathrm{R}$ & $\mathbf{F}$ & & & & & & R & $\mathrm{R}$ & & & $\begin{array}{l}\text { Dictyocha messan- } \\
\text { ensis aculeata }\end{array}$ \\
\hline $3 \mathrm{H}, \mathrm{cc}$ & & & & & $R$ & & $F$ & $R$ & & & $R$ & & $R$ & $R$ & & & $\mathbf{R}$ & & - & & & $R$ & $R$ & $\begin{array}{l}\text { Mesocena } \\
\text { quadrangula }\end{array}$ \\
\hline $\begin{array}{l}4 \mathrm{H}, \mathrm{cc} \\
5 \mathrm{X}, \mathrm{cc} \\
6 \mathrm{X}, \mathrm{cc} \\
7 \mathrm{X}, \mathrm{cc} \\
8 \mathrm{X}, \mathrm{cc} \\
9 \mathrm{X}, \mathrm{cc} \\
10 \mathrm{X}, \mathrm{cc} \\
11 \mathrm{X}, \mathrm{cc}\end{array}$ & & & & $\begin{array}{l}R \\
R \\
F\end{array}$ & 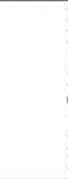 & $\begin{array}{l}\mathrm{R} \\
\mathrm{F} \\
\mathrm{F} \\
\mathrm{F} \\
\mathrm{C} \\
\mathrm{R} \\
\mathrm{R}\end{array}$ & & $\begin{array}{l}\mathrm{R} \\
\mathrm{C} \\
\mathrm{C} \\
\mathrm{C} \\
\mathrm{F} \\
\mathrm{R} \\
\mathrm{R} \\
\mathrm{R}\end{array}$ & $\bullet$ & $\begin{array}{ll} & R \\
R & \\
R & \\
R & \\
R & \end{array}$ & & $\mathrm{R}$ & $\begin{array}{l}\mathrm{R} \\
\mathrm{C} \\
\mathrm{R}\end{array}$ & $\begin{array}{l}R \\
R \\
F \\
R \\
F \\
F \\
F \\
F\end{array}$ & R & & & & & $\begin{array}{l}\mathrm{R} \\
\mathrm{R} \\
\mathrm{R} \\
\mathrm{F}\end{array}$ & $\begin{array}{l}\mathrm{R} \\
\mathrm{R} \\
\mathrm{R} \\
\mathrm{R}\end{array}$ & $\mathrm{F}$ & $\begin{array}{l}\mathrm{R} \\
\mathrm{F} \\
\mathrm{R}\end{array}$ & $\begin{array}{l}\text { Dictyocha messan- } \\
\text { ensis stapedia }\end{array}$ \\
\hline $\begin{array}{l}12 X, c c \\
13 X, c c \\
14 X, c c \\
15 X, c c \\
16 X, c c \\
17 X, c c \\
18 X, c c \\
19 X, c c \\
20 X, c c \\
21 X, c c \\
22 X-1 \\
23 X-1 \\
24 X, c c \\
25 X, c c \\
26 X, c c \\
27 X, c c \\
\end{array}$ & & R & - & $\mathrm{R}$ & & - & $\mathrm{F}$ & & $\begin{array}{l}\mathrm{R} \\
\mathrm{R} \\
\mathrm{R} \\
\mathrm{F} \\
\mathrm{R} \\
\mathrm{R} \\
\mathrm{R} \\
\mathrm{F} \\
\mathrm{R} \\
\mathrm{F} \\
\mathrm{R} \\
\mathrm{R}\end{array}$ & & & $\begin{array}{l}R \\
F \\
R \\
R \\
R \\
\\
R \\
R \\
R \\
R\end{array}$ & $\mathrm{R}$ & $\begin{array}{l}R \\
R \\
R \\
R \\
R \\
R \\
R \\
R \\
R \\
R \\
R \\
R \\
R \\
R \\
R \\
R \\
R\end{array}$ & & $\mathbf{R}$ & & $\mathrm{R}$ & & $\begin{array}{l}\mathrm{R} \\
\mathrm{R} \\
\mathrm{R} \\
\mathrm{R} \\
\mathrm{R}\end{array}$ & R & $\mathrm{R}$ & $\mathrm{R}$ & Dictyocha varia \\
\hline $\begin{array}{l}28 X, c c \\
29 X, c c \\
30 X, c c \\
31 X, c c \\
32 X, c c \\
33 X, c c \\
34 X, c c\end{array}$ & & & $\begin{array}{l}\mathrm{R} \\
\mathrm{F}\end{array}$ & & & & & & $\begin{array}{l}\mathrm{R} \\
\mathrm{C} \\
\mathrm{R} \\
\mathrm{R} \\
\mathrm{R}\end{array}$ & & & $\begin{array}{l}\mathrm{R} \\
\mathrm{F} \\
\mathrm{F} \\
\mathrm{R}\end{array}$ & $\mathrm{R}$ & $\begin{array}{l}\mathrm{F} \\
\mathrm{F} \\
\mathrm{C}\end{array}$ & . & $\mathrm{R}$ & & $\begin{array}{l}\mathrm{R} \\
\mathrm{R} \\
\mathrm{R}\end{array}$ & & $\begin{array}{l}R \\
R \\
R \\
R \\
R \\
R\end{array}$ & $\mathrm{R}$ & $R$ & F & $\begin{array}{l}\text { Corbisema } \\
\text { triacantha }\end{array}$ \\
\hline $\begin{array}{l}35 \mathrm{X}-1 \\
36 \mathrm{X}, \mathrm{cc} \\
\end{array}$ & $\mathrm{F}$ & & & & & & & & & & & $\mathrm{R}$ & & $\mathrm{R}$ & & & $\begin{array}{l}\mathrm{R} \\
\mathrm{R}\end{array}$ & & $R$ & R & $\mathrm{R}$ & & & $\begin{array}{l}\text { Naviculopsis- } \\
\text { Assemblage }\end{array}$ \\
\hline $37 \mathrm{X}-43 \mathrm{X}, \mathrm{cc}$ & & & & & & & & & & & & & irren & & & & & & & & & & & $?$ \\
\hline
\end{tabular}

Note: $\mathrm{R}=$ rare, $\mathrm{F}=$ few, $\mathrm{C}=$ common, $\mathrm{A}=$ abundant, $\bullet=$ displaced.

messanensis stapedia was used to identify the top of the Dictyocha varia Zone, which is slightly below the last occurrence of $P$. apiculata.

\section{Dictyocha messanensis stapedia Zone}

Definition. Interval from the first occurrence of Dictyocha messanensis stapedia to the first occurrence of Mesocena quadrangula. Upper Miocene (part) and Pliocene.

Occurrence. Found at Sites 679 through 684 and 686 through 688.

Remarks. Paramesocena circulus is too rare in the present material to be useful for defining the top of the $D$. messanensis stapedia Zone, thus the first occurrence of Mesocena quadrangula was used as the datum indicator, although this species shows inconsistent first occurrences elsewhere.

\section{Mesocena quadrangula Zone}

Definition. Interval from the first to the last occurrence of Mesocena quadrangula (Martini, 1971).

Occurrence. Found at Sites 680 through 688.

Remarks. The last occurrence of $M$. quadrangula seems to be consistent at a certain level, which has been shown to be between the Jaramillo and Brunhes events of the magnetostratigraphic subdivision and which has been dated 0.79 m.y. (see Harland et al., 1982). The first occurrence of $M$. quadrangula has been the subject of some debate and seems to be inconsistent over large areas (e.g. Dumitrica, 1973a). However, during Leg 112 off Peru, this species seemed to occur first rather consistently in the lowest part of calcareous nannoplankton Zone NN19 (Pseudoemiliania lacunosa Zone) in the early Pleistocene and is a valuable marker in the eastern Pacific off Peru.

\section{Dictyocha messanensis aculeata Zone}

Definition. Interval above the last occurrence of Mesocena quadrangula (Dumitrică, 1973b, as M. elliptica).

Occurrence. Encountered at Sites 680 through 688 .

Remarks. Members of the Dictyocha messanensis group and Distephanus bioctonarius group are the only silicoflagellates left in this area and, in some rare cases, are associated with Distephanus speculum.

\section{SITE SUMMARIES}

\section{Site $679\left(11^{\circ} 03.52^{\prime} \mathrm{S}, 7^{\circ} 15.92^{\prime} \mathrm{W}\right.$; water depth, $439.5 \mathrm{~m})$}

Silicoflagellates occurred in Holes 679B, 679C, and 679D at various levels and were associated with abundant diatoms and rare sponge spicules. Only Hole 679D was studied in detail for silicoflagellates, although barren intervals in Cores 112-679D-1H, $-5 \mathrm{H},-10 \mathrm{H},-22 \mathrm{X},-24 \mathrm{X}$, and $-26 \mathrm{X}$ and a low diversity in species do not allow a reliable stratigraphic resolution. Between Cores 112-679D-2H and $-4 \mathrm{H}$, Dictyocha messanensis aculeata is present. Distephanus bioctonarius $\mathrm{f}$. bioctonarius was noted in Sample 112-679D-2H, CC, but Mesocena quadrangula was not found. Because the latter was observed frequently at all other sites, Cores $112-679 \mathrm{D}-2 \mathrm{H}$ to $-4 \mathrm{H}$ may belong in the late Quaternary 
Table 2. Distribution of silicoflagellates, actiniscidians, and ebridians in selected samples and indication of silicoflagellate zones, Holes 683A and 683B.

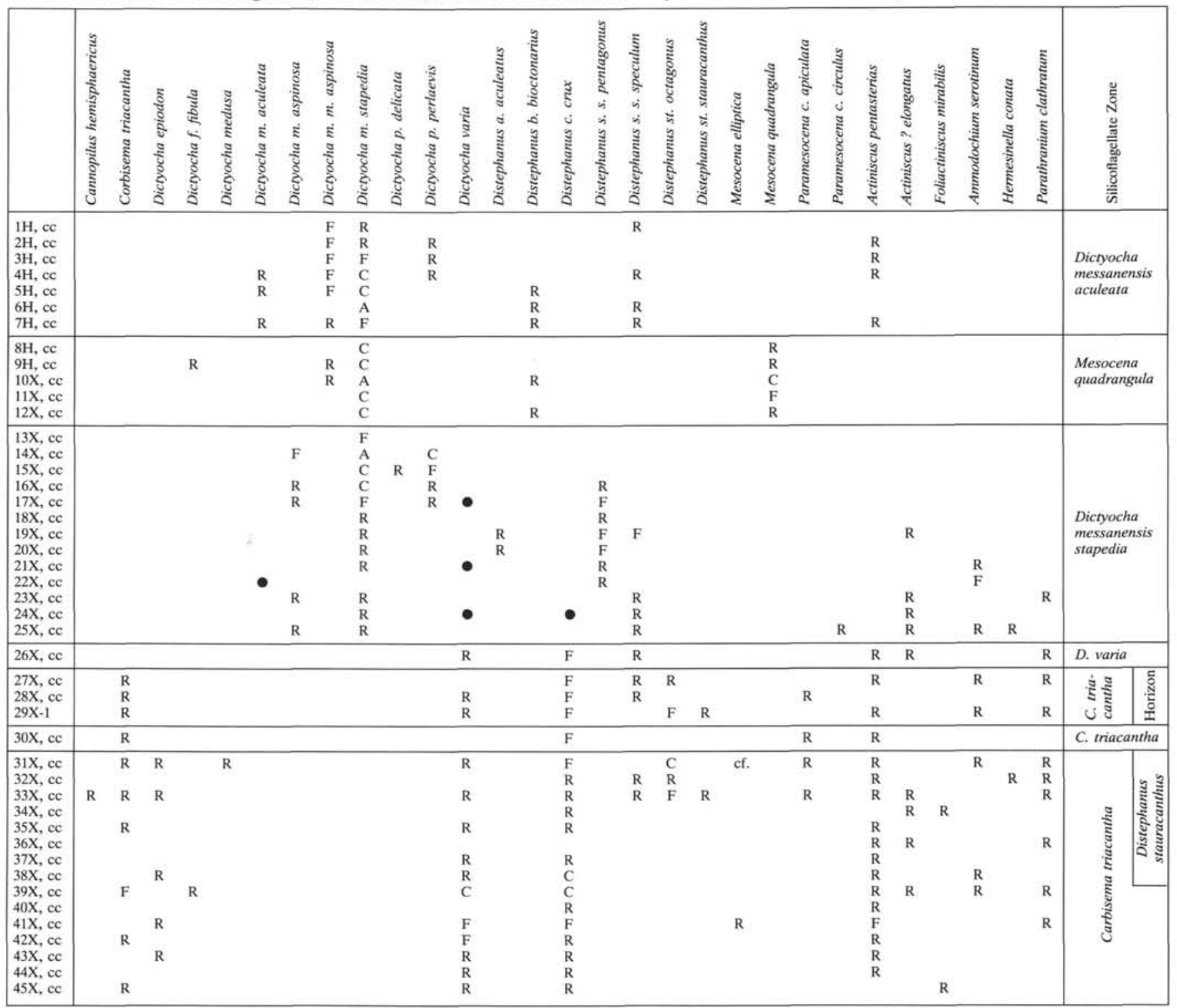

interval above the last occurrence of Mesocena quadrangula at 0.79 m.y. Below the barren interval in Core $112-679 \mathrm{D}-5 \mathrm{H}$, a change was noted in the silicoflagellate assemblage, which in Samples 112-679D-6H, CC (53.3 mbsf) and -8H, CC (74.1 mbsf) consists of Distephanus speculum and D. speculum $\mathrm{f}$. pseudofibula of probably early Pliocene age, indicating a hiatus somewhere between Samples 112-679D-4H, CC, and $-6 \mathrm{H}, \mathrm{CC}$. In Core 112-679D-15H and below, Distephanus crux and Dictyocha varia occur sporadically. A single specimen of Distephanus stauracanthus f. octagonus was noted in Sample 112-679D-25X, CC (217.2 mbsf).

In Hole 679E, a silicoflagellate assemblage containing Distephanus speculum $\mathrm{f}$. pseudofibula was found in phosphate nodules recovered in Sample 112-679E-1X, CC, but this is considered downhole contamination from a higher stratigraphic level. Samples below, down to the terminal depth at $359.3 \mathrm{~m}$, are barren in silicoflagellates.

\section{Site $680\left(11^{\circ} 03.90^{\prime} \mathrm{S}, 7^{\circ} 04.67^{\prime} \mathrm{W}\right.$; water depth, $252.5 \mathrm{~m}$ )}

Silicoflagellates occur in most samples of the three holes. They are associated with abundant diatoms, some sponge spicules, and very rare actiniscidians. Representatives of the Distephanus speculum group and Dictyocha messanensis group are the most common forms in the silicoflagellate assemblages. The only Mesocena species found was Mesocena quadrangula in Samples 112-680A-4H, CC, through -6H, CC and 112$680 \mathrm{~B}-5 \mathrm{H}, \mathrm{CC}$, which are of Pleistocene age. Distephanus bioctonarius $\mathrm{f}$. bioctonarius was noted at several levels between Samples $112-680 \mathrm{~A}-1 \mathrm{H}, \mathrm{CC}$, and $-6 \mathrm{H}, \mathrm{CC}$, and between Samples 112680B-2H-2, 96-97 cm, and $-4 \mathrm{H}-2,90-91 \mathrm{~cm}$.

Samples from the lower part of the sequence, as recovered in Hole $680 \mathrm{~B}$, are more or less barren in silicoflagellates, with the exception of Samples 112-680B-14X, CC, $-19 \mathrm{X}, \mathrm{CC},-21 \mathrm{X}, \mathrm{CC}$, and $-22 \mathrm{X}$, CC. In Samples 112- 
Table 3. Distribution of silicoflagellates, actiniscidians, and ebridians in selected samples from Hole $685 \mathrm{~A}$ and indication of silicoflagellate zones.

\begin{tabular}{|c|c|c|c|c|c|c|c|c|c|c|c|c|c|c|c|c|c|c|c|c|c|c|c|c|c|c|c|c|c|c|}
\hline & 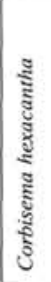 & 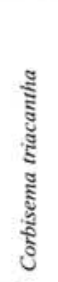 & 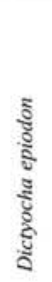 & 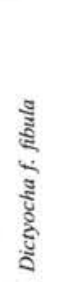 & 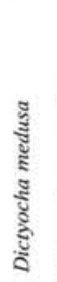 & 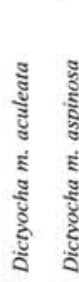 & 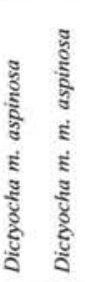 & 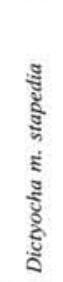 & 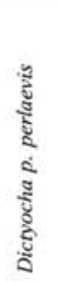 & $\begin{array}{l}\text { हूँ } \\
\frac{\pi}{g} \\
\frac{5}{5} \\
\text { है }\end{array}$ & 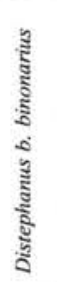 & 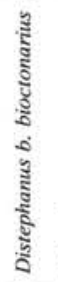 & 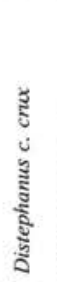 & 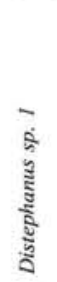 & 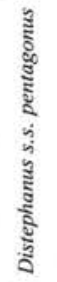 & 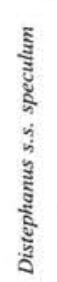 & 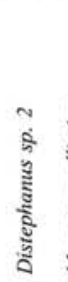 & 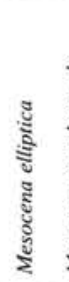 & 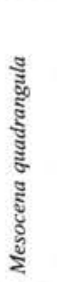 & 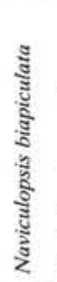 & 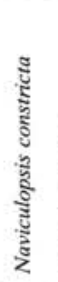 & 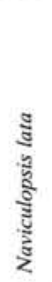 & 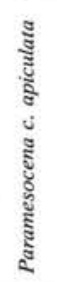 & 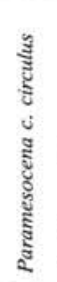 & 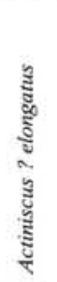 & $\begin{array}{l}\text { हूँ } \\
\text { हूँ } \\
\text { हूँ } \\
\text { हूँ } \\
\text { हूँ }\end{array}$ & 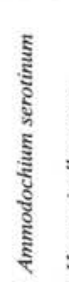 & 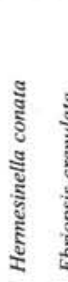 & 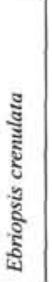 & 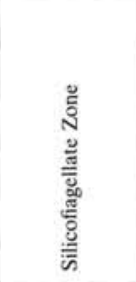 \\
\hline $\begin{array}{l}1 \mathrm{H}, \mathrm{cc} \\
2 \mathrm{H}, \mathrm{cc} \\
3 \mathrm{H}, \mathrm{cc} \\
4 \mathrm{H}, \mathrm{cc} \\
5 \mathrm{X}, \mathrm{cc} \\
6 \mathrm{X}, \mathrm{cc} \\
7 \mathrm{X}, \mathrm{cc}\end{array}$ & & & & & & $\begin{array}{l}\mathrm{R} \\
\mathrm{R} \\
\mathrm{R} \\
\mathrm{R} \\
\mathrm{F}\end{array}$ & $\begin{array}{l}\text { F } \\
\text { F } \\
\text { C } \\
\text { F } \\
\text { C } \\
\text { C } \\
\text { C }\end{array}$ & $\begin{array}{l}\mathrm{R} \\
\mathrm{R} \\
\mathrm{R}\end{array}$ & $\begin{array}{l}\mathrm{F} \\
\mathrm{F} \\
\mathrm{R} \\
\mathrm{R}\end{array}$ & & $R$ & $\begin{array}{l}R \\
R\end{array}$ & & 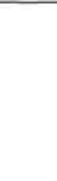 & $\mathrm{R}$ & $\begin{array}{l}R \\
R \\
R \\
R \\
R \\
R\end{array}$ & & & & & & & & & & $\begin{array}{l}\mathrm{R} \\
\mathrm{R} \\
\mathrm{R}\end{array}$ & & & & $\begin{array}{l}\text { Dictyocha } \\
\text { messanensis } \\
\text { aculeata }\end{array}$ \\
\hline $\begin{array}{l}8 \mathrm{X}, \mathrm{cc} \\
9 \mathrm{X}, \mathrm{cc} \\
10 \mathrm{X}, \mathrm{cc} \\
11 \mathrm{X}, \mathrm{cc} \\
12 \mathrm{X}, \mathrm{cc} \\
13 \mathrm{X}, \mathrm{cc} \\
14 \mathrm{X}, \mathrm{cc} \\
15 \mathrm{x}, \mathrm{cc} \\
16 \mathrm{X}, \mathrm{cc} \\
17 \mathrm{X}, \mathrm{cc} \\
18 \mathrm{X}, \mathrm{cc} \\
19 \mathrm{X}, \mathrm{cc} \\
20 \mathrm{X}, \mathrm{cc} \\
21 \mathrm{X}, \mathrm{cc} \\
22 \mathrm{X}, \mathrm{cc}\end{array}$ & & & & & & $\begin{array}{l}R \\
R \\
R\end{array}$ & $\begin{array}{l}\mathrm{F} \\
\mathrm{F} \\
\mathrm{R} \\
\mathrm{C} \\
\mathrm{R} \\
\mathrm{R} \\
\mathrm{R}\end{array}$ & $\begin{array}{l}\mathrm{C} \\
\mathrm{F} \\
\mathrm{R} \\
\mathrm{C} \\
\mathrm{F} \\
\mathrm{F} \\
\mathrm{F} \\
\mathrm{F} \\
\mathrm{F} \\
\mathrm{F} \\
\mathrm{C} \\
\mathrm{C} \\
\mathrm{F} \\
\mathrm{F} \\
\mathrm{R}\end{array}$ & $\begin{array}{l}\mathrm{R} \\
\mathrm{R}\end{array}$ & & & $\begin{array}{l}R \\
R\end{array}$ & $\bullet$ & & & R & $\mathbf{R}$ & & $\begin{array}{l}\mathrm{R} \\
\mathrm{R} \\
\mathrm{R} \\
\mathrm{F} \\
\mathrm{F} \\
\mathrm{F}\end{array}$ & & & & & & & $\begin{array}{l}\mathrm{R} \\
\\
\mathrm{R} \\
\mathrm{R}\end{array}$ & & $\mathbf{R}$ & & $\begin{array}{l}\text { Mesocena } \\
\text { quadrangula }\end{array}$ \\
\hline $\begin{array}{l}23 X, c c \\
24 X, c c \\
25 X, c c \\
26 X, c c \\
27 X, c c \\
28 X, c c \\
29 X, c c \\
30 X, c c \\
31 X, c c \\
32 X, c c \\
33 X, c c \\
34 X, c c \\
35 X, c c \\
36 X, c c \\
37 X, c c \\
38 X, c c \\
39 X, c c \\
40 X, c c \\
41 X, c c \\
42 X, c c \\
43 X, c c \\
44 X, c c \\
45 X, c c \\
46 X, c c \\
47 X, c c \\
48 X, c c \\
49 X, c c \\
50 X, c c \\
51 X, c c \\
\end{array}$ & $:$ & - & $\begin{array}{l}\mathrm{R} \\
\mathrm{R} \\
\mathrm{R} \\
\mathrm{R} \\
\mathrm{F} \\
\mathrm{R} \\
\mathrm{R} \\
\mathrm{R} \\
\mathrm{R} \\
\mathrm{R}\end{array}$ & $\mathrm{R}$ & $R$ & & & $?$ & 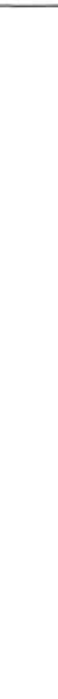 & $\begin{array}{l}R \\
R \\
R \\
R \\
R \\
R \\
R \\
R\end{array}$ & 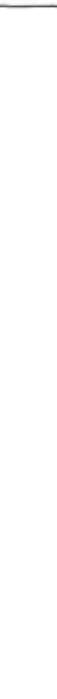 & & $\begin{array}{l}R \\
R \\
R\end{array}$ & $\mathrm{R}$ & & $\begin{array}{l}F \\
F \\
R \\
R \\
\\
\\
R \\
R \\
R \\
R\end{array}$ & & $\mathbf{R}$ & & $\bullet$ & $\bullet$ & - & $\begin{array}{l}\mathrm{R} \\
\mathrm{R}\end{array}$ & $?$ & $\begin{array}{l}\mathrm{R} \\
\mathrm{R} \\
\mathrm{R} \\
\mathrm{R}\end{array}$ & $\begin{array}{l}\mathrm{R} \\
\mathrm{R} \\
\mathrm{R} \\
\mathrm{R} \\
\mathrm{R} \\
\mathrm{R} \\
\\
\\
\mathrm{R}\end{array}$ & & $R$ & $\bullet$ & $\begin{array}{l}\text { Dictyocha } \\
\text { varia }\end{array}$ \\
\hline
\end{tabular}

$680 \mathrm{~B}-19 \mathrm{X}, \mathrm{CC}$, and $-22 \mathrm{X}, \mathrm{CC}$, of probably early Pliocene age, rare Distephanus crux and a Goniothecium species were found. Because of the low diversity in species and barren intervals of the sequence, only the upper part can be placed in silicoflagellate zones. The interval from the top down to Sample 112-680A-3H, CC, belongs to the Dictyocha messanensis aculeata Zone, and the interval between Samples $112-680 \mathrm{~A}-4 \mathrm{H}, \mathrm{CC}$, and $-6 \mathrm{H}, \mathrm{CC}$, represents the Mesocena quadrangula Zone.

$$
\begin{gathered}
\text { Site } 681\left(10^{\circ} 58.60^{\prime} \mathrm{S}, 77^{\circ} 57.46^{\prime} \mathrm{W} ;\right. \\
\text { water depth, } 150.5 \mathrm{~m})
\end{gathered}
$$

At this site, silicoflagellates are present throughout the Quaternary sequence, although some barren intervals were noted and are associated with abundant diatoms, rare sponge spicules, and, occasionally, with actiniscidians. As in the previous sites, specimens of the Dictyocha messanensis group were the most common forms observed. The lowest occurrences of Distephanus bioctonarius $\mathrm{f}$. bioctonarius were noted in Samples 112-681A-13X, CC, -681B-13X, CC, and -681C$9 \mathrm{H}, \mathrm{CC}$. A co-occurrence of this species with Mesocena quadrangula was found between Samples 112-681A-7H-1, $101-102 \mathrm{~cm}$, and $-10 \mathrm{H}, \mathrm{CC}$, and in Samples 112-681B-10H, $\mathrm{CC}$ and $-681 \mathrm{C}-9 \mathrm{H}, \mathrm{CC}$, supporting a Pleistocene age assignment. However, the last occurrence of $M$. quadrangula may be higher in the sequence, since Cores 112-681A-5H (part) and $-6 \mathrm{H}$ were barren in silicoflagellates. For details of the $D$. bioctonarius group, see the systematic reference section and Table 5 .

\section{Site $682\left(11^{\circ} 15.99^{\prime} \mathrm{S}, 7^{\circ} 03.73^{\prime} \mathrm{W}\right.$; water depth, $3788.5 \mathrm{~m}$ )}

All core-catcher samples and some additional samples were studied for silicoflagellates, which are present from the top of the hole down to Core 112-682A-36X, covering the whole Neogene and Quaternary sequences, although their occurrence in the lowest Miocene is scarce owing to the low opal content of the sediments. 
Table 4. Distribution of silicoflagellates in selected samples from Holes $688 \mathrm{~A}, 688 \mathrm{C}$, and $688 \mathrm{E}$ and indication of silicoflagellate zones.

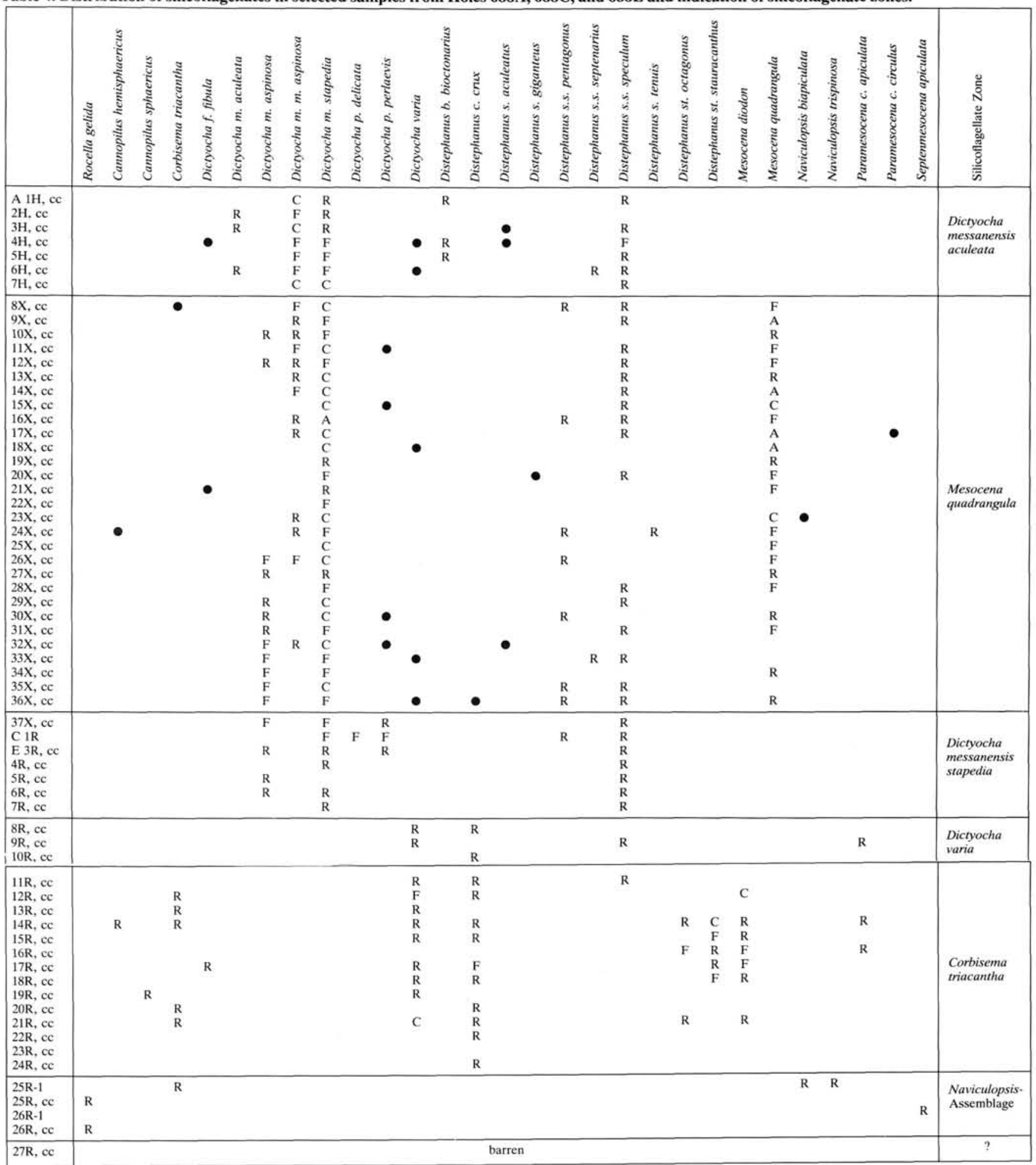

The lowest occurrence of Distephanus bioctonarius $\mathrm{f}$. bioctonarius was found in Sample 112-682A-3H-3, 69-70 $\mathrm{cm}$. Mesocena quadrangula is present in Core $112-682 \mathrm{~A}-3 \mathrm{H}$ and in Section 112-682A-4H-4. In Samples 112-682A-4H, $\mathrm{CC}$ and $-7 \mathrm{H}, \mathrm{CC}$, Distephanus aculeatus (syn. D. boliviensis) was observed, indicating an interval in the middle
Pliocene, which is in accordance with calcareous nannoplankton data at this level and also with a hiatus in the lowest part of Core 112-682A-4H. The change from frequent Dictyocha messanensis stapedia (with vertical apical bar) to frequent Dictyocha varia (with horizontal apical bar), which was found to be a useful datum already in early stratigraph- 


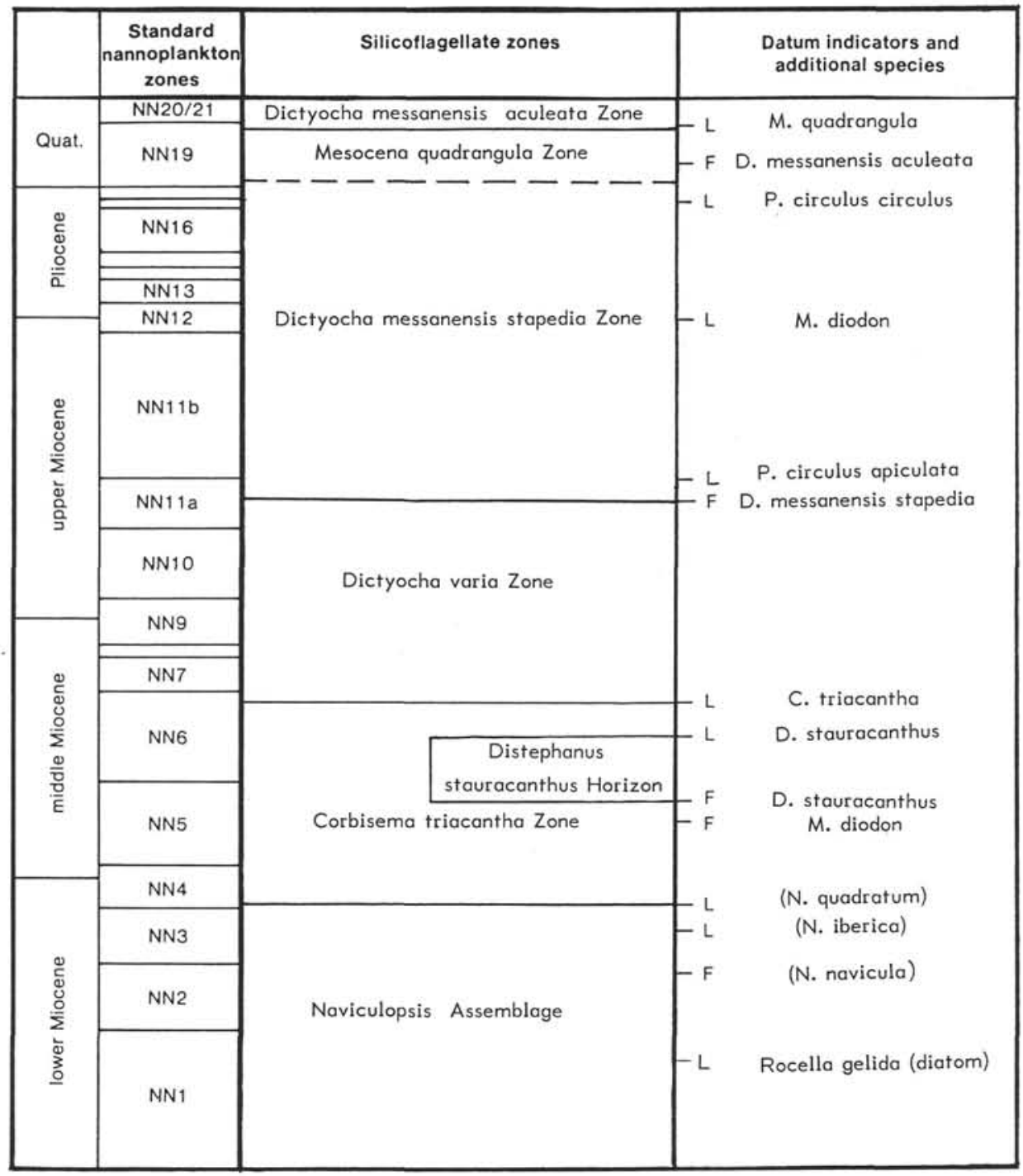

Figure 2. Silicoflagellate zones used for Leg 112 sites, first and last occurrences of important silicoflagellate species, and correlation to standard nannoplankton zones (SNZ, Martini, 1971, and this volume).

ical studies of silicoflagellates (Martini, 1971: frequency change "D. fibula/D. rhombica") and which takes place in the lower part of the late Miocene calcareous nannoplankton Zone NN11 (Martini, 1976), was noted in Core 112-682A13X. In Samples 112-682A-21X, CC and -22X, CC, several specimens of Distephanus stauracanthus $\mathrm{f}$. octagonus were encountered well above the occurrence of the Distephanus stauracanthus Horizon in Hole 682A. The base of the Dictyocha varia Zone was placed in Core 112-682A-28X, where the last occurrence of Corbisema triacantha was found. In Core 112-682A-31X, the Distephanus stauracanthus Horizon was identified. The base of the Corbisema triacantha Zone is between Cores 112-682A-34X and -35X, because in Sample 112-682A-35X-1, 21-22 cm, rare Naviculopsis biapiculata were encountered. This species has its last occurrence in the early Miocene.

The silicoflagellates are associated with common to abundant diatoms, rare to few sponge spicules, and, occasionally, with ebridians and actiniscidians. These include Actiniscus pentasterias, A. ? elongatus as well as Parathranium clathra- tum and Ammodochium serotinum, found in low numbers throughout the early Miocene to Quaternary sequences of Hole 682A. Below Core 112-682A-36X, samples are barren of these siliceous microfossils (For details, see Table 1).

\section{Site $683\left(9^{\circ} 01.69^{\prime} \mathrm{S}, 80^{\circ} 24.40^{\prime} \mathrm{W}\right.$; water depth, $3071.8 \mathrm{~m}$ )}

Silicoflagellates or actiniscidians are present from the top of Hole $683 \mathrm{~A}$ down to Core 112-683A-45X (418 mbsf), covering part of the Neogene and the Quaternary intervals.

The Pliocene and Quaternary intervals (Cores 112-683A$1 \mathrm{H}$ to $-28 \mathrm{X}, 0.0$ to $228.2 \mathrm{mbsf}$ ) show close similarities with the previous Sites 680 to 682 . Dictyocha messanensis aculeata was found only in Sample 112-683A-7H, CC $(59.2$ mbsf), but Mesocena quadrangula and Distephanus bioctonarius $\mathrm{f}$. bioctonarius were observed in several samples. The lowest occurrence of $D$. bioctonarius $\mathrm{f}$. bioctonarius was noted in Sample 112-683A-12X, CC (106.7 mbsf) within the range of Mesocena quadrangula, which occurs between Samples 112-683A-8H, CC and -13X-1, 38-39 cm 
(68.7-126.1 mbsf). Between Cores 112-683A-16X and -22X (137.1-193.0 mbsf) Distephanus speculum speculum f. pentagonus is a frequently found constituent. Dictyocha messanensis stapedia and related forms that have a vertical bar were found down to Core 112-683A-25X (228.3 mbsf).

Below Core 112-683A-25X, the silicoflagellate assemblages show a distinct change, indicating a hiatus between Cores 112-683A-25X and -26X, with part of the lowest Pliocene and the upper Miocene intervals missing. Corbisema triacantha occurs from Core 112-683A-27X downward with dictyoid forms having a horizontal apical bar, most of which belong to Dictyocha varia, and are present from Core 112-683A-27X down to the base of the hole in varying abundance. The rather common occurrence of Distephanus stauracanthus $\mathrm{f}$. octagonus in Cores 112-683A$27 \mathrm{X},-29 \mathrm{X},-31 \mathrm{X}$ to $-33 \mathrm{X}$, and again in Core 112-683A-38X, together with D. stauracanthus $\mathrm{f}$. stauracanthus in Sample 112-683A-29X-1, 17-18 cm, indicates the D. stauracanthus Horizon, although most of the interval between Core 112$683 \mathrm{~A}-27 \mathrm{X}$ and the terminal Core $112-683 \mathrm{~A}-45 \mathrm{X}$ seems to represent disturbed slump material, but in a continuous sequence. The most common forms in this part of the interval are those of the Distephanus crux group. Within this sequence, Core 112-683A-30X is of special interest as it contains Distephanus crux and Paramesocena circulus apiculata. However, neither Distephanus stauracanthus f. octagonus nor D. stauracanthus $\mathrm{f}$. stauracanthus was found. This core may represent a younger horizon, although it still contains rare Corbisema triacantha. This seems to agree with the determination of the late middle Miocene calcareous nannoplankton Zone NN8 (Catinaster coalitus Zone) in this particular core (Martini, this volume). For details, see Table 2.

Silicoflagellates were noted in Cores 112-683B-1X to $-6 \mathrm{X}$ in Hole 683B and include Dictyocha varia and members of the Distephanus crux group, indicating a middle Miocene age. Below a hiatus, only a few displaced Miocene species were found in Cores 112-683B-8X and -9X; they might represent downhole contamination during coring. The Eocene section in Cores 112-683B-7X through -9X otherwise is barren in silicoflagellates.

Actiniscidians and ebridians were observed in various samples throughout Hole 683A and in Cores 112-683B-1X to $-6 \mathrm{X}$, with Actiniscus pentasterias as the most common species. Actiniscus ? elongatus was noted only between Cores 112-683A-19X and -39X in Hole 683A, and Parathranium clathratum, Ammodochium serotinum, as well as Hermesinella conata occur sporadically in the slumped material below Core 112-683A-25X in Hole 683A and down to Core $112-683 \mathrm{~B}-6 \mathrm{X}$ in Hole $683 \mathrm{~B}$.

\section{Site $684\left(8^{\circ} 59.59^{\prime} \mathrm{S}, 79^{\circ} 54.35^{\prime} \mathrm{W}\right.$; water depth, $426.0 \mathrm{~m}$ )}

All core-catcher and some additional samples were studied for silicoflagellates in Hole $684 \mathrm{~A}$; none were investigated from Holes $684 \mathrm{~B}$ and $684 \mathrm{C}$. Three intervals with different silicoflagellate assemblages can be distinguished.

Core 112-684A-1H and most of Core $112-684 \mathrm{~A}-2 \mathrm{H}$ contain a meager Quaternary assemblage that includes Distephanus bioctonarius $\mathrm{f}$. bioctonarius, which has its lowest occurrence in this hole in Sample 112-684A-2H-4, 27-28 cm (10.7 mbsf).

In Cores $112-684 \mathrm{~A}-3 \mathrm{H}$ to $-6 \mathrm{H}$, the most common silicoflagellates belong to Dictyocha messanensis stapedia and related forms having a vertical apical bar and Distephanus speculum speculum f. speculum. In Sample 112-684A$3 \mathrm{H}-4,109-110 \mathrm{~cm}$ (20.4 mbsf) Paramesocena circulus and in
Sample 112-684A-5H, CC Distephanus aculeatus (syn. D. boliviensis) were found. Together with calcareous nannoplankton data for this part of the sequence (Martini, this volume), these species indicate a late Pliocene age for this interval.

Samples from Cores $112-684 \mathrm{~A}-7 \mathrm{H}$ to $-14 \mathrm{X}$ are dominated by Distephanus crux and Dictyocha varia. In Sample 112684A-7H, CC (61.8 mbsf) rather frequent Mesocena diodon were found, which ranges throughout the middle and late Miocene into the basal Pliocene (calcareous nannoplankton Zones NN5 to NN13). Rare Paramesocena circulus were noted in Samples 112-684A-8H-1, 9-10 cm (62.4 mbsf) and $-12 \mathrm{X}, \mathrm{CC}$ (98.1 mbsf). The assemblage of this interval can be placed in the late middle to early late Miocene Dictyocha varia Zone (Locker and Martini, 1986a).

Based on silicoflagellate assemblages and their age assignment, two hiatuses are postulated. The first is located in the lowest part of Core $112-684 \mathrm{~A}-2 \mathrm{H}$ at approximately $15 \mathrm{mbsf}$ with the lower Pleistocene and part of the upper Pliocene intervals missing, and the second between Cores $112-684 \mathrm{~A}-6 \mathrm{H}$ and $-7 \mathrm{H}$ at approximately $51 \mathrm{mbsf}$. Here, the lower Pliocene and most of the upper Miocene intervals are missing.

Actiniscidians and ebridians were found scattered throughout the sequence and include Actiniscus pentasterias between Samples 112-684A-7H, CC and -14X, CC, A.? elongatus in Samples 112-684A-6H, CC, and -14X, CC, and Parathranium clathratum between Samples 112-684A-3H, CC and -13X, CC.

\section{Site $685\left(9^{\circ} 06.78^{\prime} \mathrm{S}, 80^{\circ} 35.01^{\prime} \mathrm{W}\right.$; water depth, $\mathbf{5 0 7 0 . 8} \mathrm{m}$ )}

All core-catcher and some additional samples in Hole 685A were studied for silicoflagellates and some other siliceous microfossils.

Cores $112-685 \mathrm{~A}-1 \mathrm{H}$ to $-22 \mathrm{X}$ (199.8 mbsf) contain Quaternary silicoflagellate assemblages, which are associated with abundant diatoms, frequent sponge spicules, and, occasionally, actiniscidians. The most common silicoflagellates belong to the Dictyocha messanensis group; Dictyocha messanensis aculeata, indicating a late Quaternary age, was found in Samples 112-685A-5X, CC (40.4 mbsf), -6X, CC (51.4 mbsf), and 685A-11X, CC (99 mbsf). Mesocena quadrangula was observed in Sample 112-685A-8X, CC (70.8 mbsf), but is more common in the interval from Core 112-685A-14X down to Core 112-685A-22X, and has its lowest occurrence in Sample 112-685A-22X,CC (199.8 mbsf). Distephanus bioctonarius $\mathrm{f}$. bioctonarius is present in Core 112-688A-2H and in Sample 112-685A-16X, CC (142.2 mbsf).

Between Cores 112-685A-22X and -23X at approximately 200 mbsf, a hiatus (approx. $4.3 \mathrm{~m} . \mathrm{y}$. duration) divides the lower Pleistocene from the upper Miocene. The silicoflagellate assemblages in most samples between Samples 112-685A23X, CC and -685A-51X, CC (203.6-459.1 mbsf) contain Dictyocha varia, members of the Distephanus crux group and Distephanus speculum f. speculum. Dictyocha messanensis stapedia was noted in a few samples, and Paramesocena circulus apiculata was found in Samples 112-685A-28X, CC (255.7 mbsf) and -685A-32X, CC (286.6 mbsf). This interval seems to represent the late middle to early upper Miocene Dictyocha varia Zone. From Sample 112-685A-34X, CC (310 mbsf) downward, silicoflagellates and diatoms are highly fractured and not well preserved.

Reworked middle or upper Miocene silicoflagellates occur in Sample 112-685A-13X, CC (112.3 mbsf) of Quaternary age, 
and reworked Naviculopsis species from the upper Oligocene/ lower Miocene occur in the late Miocene Sample 112-685A$29 \mathrm{X}, \mathrm{CC}(256.5 \mathrm{mbsf})$. In the basal part of Core 112-685A-43X, as well as in Cores 112-685A-44X (386.3-396.1 mbsf) and -50X (450.6 mbsf), early Miocene and Paleogene silicoflagellates, such as Naviculopsis biapiculata, Naviculopsis lata, Naviculopsis foliacea, and Corbisema hexacantha, outnumber the late Miocene silicoflagellates and indicate downslope slumping during the late Miocene.

Actiniscidians were found occasionally, but seem to occur more frequently in the Miocene interval. These forms include Actiniscus pentasterias throughout the sequence and A.? elongatus between Samples 112-685A-28X, CC, and $-80 \mathrm{X}, \mathrm{CC}$. Ebridians were noted in Sample 112-685A-26X, CC (232.1 mbsf) and below between Samples 112-685A-43X, CC, and -685A-5X, CC (386.5-451 mbsf). Displaced Eocene ebridians like Ebriopsis crenulata were found frequently in the lower part of Core 112-685A-43X and in Core 112$685 \mathrm{~A}-44 \mathrm{X}$. For details on the distribution of silicoflagellates, actiniscidians, and ebridians, see Table 3 .

\section{Site $686\left(13^{\circ} 28.81^{\prime} 5,76^{\circ} 53.59^{\prime} \mathrm{W}\right.$; water depth, $446.8 \mathrm{~m}$ )}

All core-catcher samples in Hole 686A were studied for silicoflagellates. Samples 112-686A-6H, CC, $-8 \mathrm{H}, \mathrm{CC},-14 \mathrm{X}$, $\mathrm{CC},-17 \mathrm{X}, \mathrm{CC}$, and $-22 \mathrm{X}, \mathrm{CC}$, were barren in silicoflagellates. In Hole 686B, only core-catcher samples from Core 112686B-21X downward were examined.

Both sequences belong entirely in the Quaternary. The silicoflagellate assemblages are dominated by members of the Dictyocha messanensis group. Mesocena quadrangula was found in several levels from Sample 112-686A-7H, CC (55.6 mbsf) throughout the sequence down to Sample 112686B-32X, CC, at the terminal depth of $303 \mathrm{mbsf}$, showing a rather long overlap with Distephanus bioctonarius f. bioctonarius. The latter was found between Samples 112$686 \mathrm{~A}-1 \mathrm{H}, \mathrm{CC}$ (4.9 mbsf) and -686B-32X, CC (303 mbsf). In Sample 112-686A-9X, CC, a single specimen that resembles Dictyocha challengeri (see Martini and Müller, 1976: Pl. 2, Fig. 8 and Pl. 8, Fig. 3) was observed. However, this specimen has six radial spines, lacks basal pikes, and may be displaced (Pl. 4, Fig. 6).

The interval between Cores $112-686 \mathrm{~A}-1 \mathrm{H}$ and $-6 \mathrm{H}$ can be placed in the Dictyocha messanensis aculeata Zone. Samples from Cores 112-686A-7H to -686B-32X belong to the Mesocena quadrangula Zone.

\section{Site $687\left(12^{\circ} 51.78^{\prime} \mathrm{S}, 7^{\circ} 59.43^{\prime} \mathrm{W}\right.$; water depth, $306.8 \mathrm{~m}$ )}

Only core-catcher samples from Hole 687A were studied for silicoflagellates. Sandy intervals recovered in Cores 112$687 \mathrm{~A}-2 \mathrm{H},-3 \mathrm{H}$, and $-8 \mathrm{X}$ to $-11 \mathrm{X}$ were barren of silicoflagellates.

As usual, the Quaternary silicoflagellate assemblages are dominated by members of the Dictyocha messanensis group. Mesocena quadrangula was found in Samples 112687A-4H, CC (36.0 mbsf) and -13X, CC (121.1 mbsf). Distephanus bioctonarius $\mathrm{f}$. bioctonarius is present between Samples 112-687A-1H, CC (7.5 mbsf) and -17X, CC (158.3 mbsf).

In Sample 112-687A-15X, CC, Distephanus aculeatus and in Sample 112-687A-20X, CC, Distephanus crux were observed in single specimens obviously displaced from older strata.

\section{Site $688\left(11^{\circ} 32.26^{\prime} \mathrm{S}, 7^{\circ} 56.57^{\prime} \mathrm{W}\right.$; water depth, $3819.8 \mathrm{~m}$ )}

The silicoflagellate assemblages in all core-catcher samples of Hole 688A contain members of the Dictyocha messanensis group. Distephanus speculum speculum f. speculum was frequently found throughout the sequence, whereas $f$. pentagonus occurred in only a few samples. Mesocena quadrangula was observed in varying numbers between Sample 112-688A-8X, CC (68.5 mbsf) and Sample 112-688A-36X, CC (341.2 mbsf), in which it has its lowest occurrence at this site. This indicates a Pleistocene age for most of the sequence. Distephanus bioctonarius $\mathrm{f}$. bioctonarius is surprisingly rare at this site and was found only in Samples 112-688A-1H, CC and $-4 \mathrm{H}, \mathrm{CC}(36.8 \mathrm{mbsf})$, well above the last occurrence of Mesocena quadrangula.

Two samples from Hole $688 \mathrm{C}$ at 351.0 (112-688C-1R-1, 75 $\mathrm{cm})$ and 351.5 mbsf (112-688C-1R-1, bottom) contain Dictyocha perlaevis delicata and lack both Mesocena quadrangula and Paramesocena circulus circulus, which places these samples in the lowest Pleistocene or uppermost Pliocene (see also Bukry, 1976).

In Hole $688 \mathrm{E}$ Mesocena quadrangula occurs in Cores 112-688E-1R and -2R (350.0 to $356.0 \mathrm{mbsf}$ ), and Dictyocha perlaevis delicata has its lowest occurrence in Sample 112$688 \mathrm{E}-3 \mathrm{R}, \mathrm{CC}$, repeating data from the lowest part of Holes $688 \mathrm{~A}$ and $688 \mathrm{C}$.

Cores 112-688A-36X and -37X, as well as Cores 112-688E-2R and $-3 \mathrm{R}$, may be divided by a short hiatus separating the Mesocena quadrangula assemblage from the Dictyocha perlaevis delicata assemblage. A rather sudden change to a meager silicoflagellate assemblage between Samples 112-688E-3R, CC and $-4 \mathrm{R}, \mathrm{CC}$ also may indicate a hiatus. Between Samples 112-688E-4R, CC and -7R, CC,the silicoflagellate assemblage consists only of members of the Distephanus speculum group and of Dictyocha messanensis stapedia. In Sample 112-688E8R, CC (421.7 mbsf), Dictyocha varia and members of the Distephanus crux group appear. An overlap between this assemblage and the occurrence of Dictyocha messanensis stapedia was not noted, and another hiatus is suspected. The late middle to early upper Miocene Dictyocha varia Zone was recognized between Samples 112-688E-8R, CC, and -11R, CC (421.7-441.2 mbsf). In Sample 112-688E-12R, CC, the last occurrence of Corbisema triacantha was found. Samples between 112-688E$14 \mathrm{R}-3,13-14 \mathrm{~cm}$, and $-16 \mathrm{R}-1,18-16 \mathrm{~cm}$, can be placed in the Distephanus stauracanthus Horizon, with D. stauracanthus $\mathrm{f}$. stauracanthus present throughout this interval. Distephanus stauracanthus f. octogonus was found in Sample 112-688E-16R, $\mathrm{CC}$, indicating that the interval between Samples 112-688E-13R, $\mathrm{CC}$, and $-16 \mathrm{R}, \mathrm{CC}$ (460.0-689.8 mbsf) can be placed in the upper part of the middle Miocene Corbisema triacantha Zone. Mesocena diodon was observed between Cores $112-688 \mathrm{E}-12 \mathrm{R}$ and $-21 \mathrm{R}$.

Cores $112-688 \mathrm{E}-17 \mathrm{R},-18 \mathrm{R}$, and $-21 \mathrm{R}$ yielded only caved-in middle Miocene material from above. Samples from Cores 112-688E-19R, $-20 R$, and $-22 R$ to $-24 R$ contain rare specimens of Distephanus crux, and Sample 112-688E-20R, CC, also contains Corbisema triacantha. These samples are also placed in the Corbisema triacantha Zone. Sample 112-688E-25R-1, $141 \mathrm{~cm}$, certainly can be placed below the last occurrence of Naviculopsis species in the late lower Miocene because rare Naviculopsis biapiculata and Naviculopsis trispinosa were found. The latter species was reported by Perch-Nielsen (1975) in Eocene sediments from Leg 29 and seems to range into the lowest Miocene. In Samples 112-688E-25R-1, 15-16 $\mathrm{cm}$ and $-25 \mathrm{R}, \mathrm{CC}$, Rocella gelida was noted, indicating the Rocella gelida Zone of Barron (1985), which straddles the 
Oligocene/Miocene boundary. This agrees with the placement of Sample 112-688E-25R, CC in calcareous nannoplankton Zone NN1/NN2 (Martini, this volume). In Sample 112-688E$26 \mathrm{R}-1,58 \mathrm{~cm}$, a broken specimen of Septenmesocena apiculata was observed. The interval between Core 112-688E-27R and the terminal Core 112-688E-46R (593.0-775.0 mbsf) is barren in silicoflagellates. For details about the distribution of silicoflagellates at this site, see Table 4.

Displaced silicoflagellates from older strata are relatively common in the Quaternary silicoflagellate assemblage and include Corbisema triacantha, Dictyocha varia, and Naviculopsis biapiculata.

Actiniscidians and ebridians were noted occasionally and include Actiniscus pentasterias (Samples 112-688A-1H, CC, -36X, CC, 688E-7R, CC, -10R, CC, -11R, CC, -17R, CC, -20R, $\mathrm{CC}$, and $-26 \mathrm{R}-1,58 \mathrm{~cm}$ ), Actiniscus ? elongatus (Samples 112-688A-4H, CC, -36X, CC, and 688E-20R, CC), and Parathranium clathratum (Samples 112-688A-3H, CC, 688E$2 \mathrm{R}-1,86 \mathrm{~cm}$, and $-12 \mathrm{R}, \mathrm{CC})$. Because of their scattered occurrence, these species are not included in Table 4 .

\section{SILICOFLAGELLATES IN PISCO BASIN DIATOMITES}

During a field trip led by R. Garrison, a set of samples was collected for comparison along the exposures just north of the Hacienda Caucato Alto northwest of San Clemente. This section belongs to the upper diatomaceous member of the Miocene Pisco Formation and includes diatomites, bentonitic siltstones, and, occasionally, phosphorite bands. Samples were taken over an interval of about $25 \mathrm{~m}$ in the diatomites, with the uppermost sample at a distinct phosphorite band near the top of the ridge. Although diatoms are abundant in all samples, silicoflagellates are rare throughout. Rare to few Distephanus speculum speculum f. speculum were observed in all samples, whereas Distephanus speculum speculum $\mathrm{f}$. pentagonus was found as single specimens in only two samples. Besides Actiniscus pentasterias, which is present in all samples, Actiniscus ? elongatus was noted in one sample. In the highest sample near the phosphorite band, calcareous nannoplankton also was observed in a poorly preserved, meager assemblage containing Coccolithus pelagicus, Discoaster brouweri, Reticulofenestra pseudoumbilica, and a small Reticulofenestra species. On the basis of these long-ranging species, an exact age assignment is not possible. Samples collected from laminated porcelanites of the Caballas Formation and banded mud rocks of the Paracas Formation exposed along the Playa Yumaque south of Paracas were barren of calcareous nannoplankton and silicoflagellates.

\section{SYSTEMATIC REFERENCES AND REMARKS ON TAXA}

Most silicoflagellate taxa found in the Leg 112 sediments off Peru have been discussed in detail in an earlier study by Locker and Martini (1986a, Leg 90), where references to authors and synonyms also can be found. In some cases, Bukry (1982, Leg 68) and Perch-Nielsen (1978, Leg 29) should be consulted. The actiniscidians and ebridians are discussed in Locker and Martini (1986b, Leg 90). With regard to the present material, all taxa found are listed, and remarks have been added only for new forms and for the Distephanus bioctonarius group.

Cannopilus depressus (Ehrenberg) Locker

Cannopiius hemisphaericus (Ehrenberg) Haeckel
Cannopilus sphaericus Gemeinhardt

Corbisema hexacantha (Schulz) Deflandre

Corbisema triacantha (Ehrenberg) Hanna (Pl. 1, Fig. 1)

Dictyocha concavata Dumitrica (Pl. 1, Fig. 4)

Dictyocha epoidon Ehrenberg

Dictyocha fibula Ehrenberg subsp. fibula (Pl. 5, Fig. 1)

Dictyocha medusa Haeckel (PI. 5, Fig. 5)

Dictyocha messanensis subsp. aculeata (Lemmermann) f. aculeata (Pl. 1, Figs. 2, 3)

Dictyocha messanensis subsp. aspinosa (Bukry) Locker and Martini (PI. 1, Fig. 5)

Dictyocha messanensis Haeckel subsp. messanensis $\mathrm{f}$. aspinosa

Dictyocha messanensis subsp. stapedia (Haeckel) f. stapedia (Pl. 1, Figs. 6, 7; Pl. 5, Fig. 4)

Dictyocha perlaevis subsp. delicata Bukry (PI. 1, Fig. 8)

Dictyocha perlaevis Frenguelli subsp. perlaevis

Dictyocha varia Locker (Pl. 1, Fig. 9)

Dictyocha sp. cf. D. challengeri Martini and Müller (PI. 4, Fig. 6)

Distephanus aculeatus (Ehrenberg) f. aculeatus (Pl. 5, Fig. 7)

Distephanus aculeatus f. ornamentum (Ehrenberg)

Distephanus bioctonarius (Ehrenberg) nov. comb. (syn. Octactis pulchra Schiller)

Type species. Mesocena bioctonaria Ehrenberg, 1846.

Description. Basal ring, rounded to oval, with normally short radial spines. Spines may have considerable length in some late Pleistocene and Holocene specimens. Thin, apical ring near the basal ring, connected by slightly arched struts. No supporting pikes on the basal ring. Delicate apical ring easily breaks off, and specimens show a mesocenoid appearance.

Remarks. Ehrenberg $(1846,1854)$ described several closely related species under the genus name Mesocena from Peru and Chile. In a revision of the Ehrenberg collection, Locker (1974) designated a lectotype of Mesocena bioctonaria Ehrenberg and transferred the species with some doubts to the genus Octactis Schiller, 1925. In a more recent study, Ling and Takahashi (1985) pointed out that Octactis Schiller, 1925, is a synonym of Distephanus Stöhr, 1880. However, they did not correlate Octactis pulchra with one of Ehrenberg's taxa because of doubts about the true nature of the latter species. Most of Ehrenberg's specimens came from the same area as that investigated during Leg 112, and even though his original drawings are rather crude, the reexamination of Locker (1974) leaves no doubt that Ehrenberg's species are identical with forms found during Leg 112 off Peru. The so-called "membrane" mentioned in Locker (1974), which aroused some confusion, is an optical ghost effect and can be ignored in further discussions. Thus, Distephanus pulchra (Schiller) must be considered a synonym of Distephanus bioctonarius (Ehrenberg). In the present material $D$. bioctonarius is represented by 7 - to 10-rayed forms named below. Their occurrence and numerical distribution in Hole $681 \mathrm{~A}$ is shown in Table 5. All six-rayed specimens, which show superficial similarity, have supporting pikes on the basal ring and belong to Distephanus speculum tenuis Bukry.

Stratigraphic occurrence. Early Pleistocene to Holocene. First occurrence in relation to the first occurrence of Mesocena quadrangula is not uniform. At Sites 680,681 , and 687 , it is prior to the first occurrence of $M$. quadrangula, at Sites 683 and 685 , shortly after the first occurrence of $M$. quadrangula, and at the offshore Sites 682 and 688 , it occurs even after the last occurrence of $M$. quadrangula.

Distephanus bioctonarius $\mathrm{f}$. binonarius (Ehrenberg) nov. comb. (Pl. 3, Figs. 5, 6) 
Table 5. Distribution of the Distephanus bioctonarius group, D. speculum tenuis, $D$. speculum speculum $\mathrm{f}$. octonarius, and Mesocena quadrangula in selected samples of Hole 681A.

\begin{tabular}{|c|c|c|c|c|c|c|c|c|c|}
\hline mbsf. & Sample & $\begin{array}{c}n \\
\vdots \\
c \\
\vdots \\
\vdots \\
n \\
n \\
s \\
c \\
5 \\
\vdots \\
\vdots \\
\vdots \\
\vdots \\
\vdots \\
0\end{array}$ & 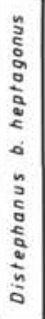 & 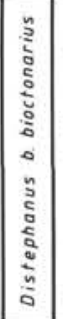 & 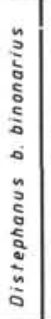 & 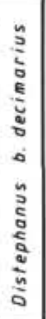 & 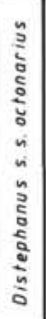 & 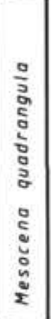 & 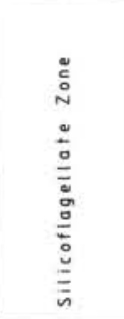 \\
\hline 0,9 & $1 \mathrm{H}-1.89-90 \mathrm{~cm}$ & & 6 & 38 & 2 & & & & \multirow{7}{*}{ 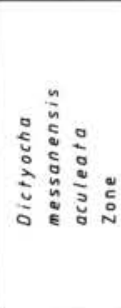 } \\
\hline 6,5 & $1 \mathrm{H}, \mathrm{CC}$ & & & 7 & 2 & & & & \\
\hline 16.2 & $2 \mathrm{H}, \mathrm{CC}$ & & & 5 & & & & & \\
\hline 25,3 & 3H, CC & & & 1 & 1 & & & & \\
\hline 33.7 & $4 \mathrm{H}, \mathrm{CC}$ & & & 9 & 2 & 2 & & & \\
\hline 37.7 & $5 \mathrm{H}-2,26-27 \mathrm{~cm}$ & & & 14 & 1 & & & & \\
\hline 40,7 & $5 \mathrm{H}-4,118-119 \mathrm{~cm}$ & & & 1 & 1 & & 5 & & \\
\hline 44.5 & SH, CC & \multirow{2}{*}{\multicolumn{7}{|c|}{ - }} & \multirow{8}{*}{ 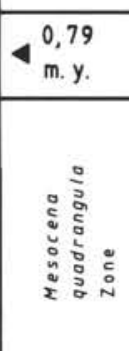 } \\
\hline 44,6 & 6H,CC & & & & & & & & \\
\hline 55.0 & $7 \mathrm{H}-1,101-102 \mathrm{~cm}$ & & & & 1 & & & 2 & \\
\hline 67.4 & $8 \mathrm{H}-1,117-118 \mathrm{~cm}$ & & & & & & & 6 & \\
\hline 73.6 & $9 \mathrm{H}-1,60-61 \mathrm{~cm}$ & & & 2 & & & & 2 & \\
\hline 82,5 & $9 \mathrm{H}, \mathrm{CC}$ & & & 1 & & & & 5 & \\
\hline 82,8 & $10 \mathrm{H}-1,27-28 \mathrm{~cm}$ & & 1 & 2 & 1 & & & & \\
\hline 88.2 & $10 \mathrm{H}, \mathrm{CC}$ & & & 3 & & & & 1 & \\
\hline 99,2 & $11 \mathrm{H}, \mathrm{CC}$ & & & 1 & & & & & \multirow{4}{*}{ 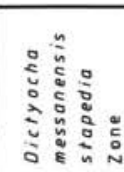 } \\
\hline 111,2 & $12 \mathrm{H}, \mathrm{CC}$ & 3 & & & & & & & \\
\hline 115,4 & $13 x, c 6$ & 3 & & 3 & & & & & \\
\hline 125,1 & $14 \times, c c$ & 7 & & & & & & & \\
\hline Total Hole & $681 \mathrm{~A}$ & 13 & 7 & 87 & 11 & 2 & 5 & 16 & \\
\hline Total Leg & 112 & 21 & 7 & 159 & 15 & 2 & 5 & & \\
\hline
\end{tabular}

Note: Numbers refer to specimens found in four traverses, each 40 -mm long, across routine smear slides viewed with a $12.5 \mathrm{X}$ ocular and $25 \mathrm{X}$ objective.

Remarks. Nine-rayed form of $D$. bioctonarius. In the present material, found at Sites $680,681,684,685$, and 687 off Peru.

Distephanus bioctonarius $\mathrm{f}$. bioctonarius (Ehrenberg) nov. comb. (P1. 3, Figs. 3, 4)

Remarks. Most common and widespread 8-rayed form of the species. Numerous specimens found that are identical to Ehrenberg's figures and Locker's drawings of the originals.

Distephanus bioctonarius f. decimarius n.f. (Pl. 3, Figs. 7,8)

Holotype. 5M.B 13826 (Pl. 3, Figs. 7, 8)

Type locality. Eastern Pacific off Peru, Site 681, Sample 681A-4H, CC.

Diagnosis. 10-rayed form of $D$. bioctonarius.

Remarks. Very rare form in the investigated material. Found only at Site 681 off Peru.

Distephanus bioctonarius $\mathrm{f}$. heptagonus (Ehrenberg) nov. comb. (Pl. 3, Figs. 1, 2)

Remarks. Relatively rare 7-rayed form of $D$. bioctonarius, found only at Site 681 off Peru during Leg 112.

Distephanus crux subsp. bispinosus Dumitrică

Distephanus crux (Ehrenberg) subsp. crux (Pl. 2, Fig. 1)

Distephanus speculum subsp. giganteus Bukry f. giganteus (Pl. 5, Fig. 3)
Distephanus speculum subsp. speculum f. octonarius (Ehrenberg) (Pl. 5, Fig. 6)

Distephanus speculum subsp. speculum f. pentagonus Lemmermann (PI. 2, Fig. 2)

Distephanus speculum subsp. speculum f. pseudofibula Schulz (Pl. 2, Fig. 5)

Distephanus speculum subsp. speculum f. pseudoseptenarius n.f. (Pl. 2, Fig. 6)

Holotype. SM.B 13827 (Pl. 2, Fig. 6)

Type locality. Eastern Pacific off Peru, Site 679, Sample 112-679E-1X, CC.

Diagnosis. Seven-rayed form with the apical structure of $D$. speculum $\mathrm{f}$. pseudofibula, but with seven connections to the basal ring.

Remarks. Very rare form in the investigated material. Found only at Site 679 off Peru.

Distephanus speculum subsp. speculum f. septenarius (Ehrenberg) (P1. 2, Fig. 4)

Distephanus speculum (Ehrenberg) subsp. speculum $\mathrm{f}$. speculum (Pl. 2, Fig. 3)

Distephanus speculum subsp. tenuis Bukry (Pl. 3, Figs. 9, 10)

Distephanus stauracanthus $\mathrm{f}$. octagonus (Tsumura) (Pl. 2, Fig. 7)

Distephanus stauracanthus (Ehrenberg) f. stauracanthus (Pl. 2, Fig. 8)

Distephanus sp. (Pl. 2, Fig. 9)

Remarks. Eight-rayed specimen similar to Distephanus bioctonarius, but pikes on apical ring and three connected rods within apical ring. No basal pikes. Found in a Distephanus speculum f. pseudofibula dominated assemblage in Sample 112-679E-1X, CC, probably of early Pliocene age.

Mesocena diodon Ehrenberg (Pl. 4, Fig. 2)

Mesocena elliptica (Ehrenberg) Ehrenberg

Mesocena quadrangula Ehrenberg ex Haeckel (PI. 4, Figs. $1,3,4)$

Naviculopsis biapiculata (Lemmermann) Frenguelli (Pl. 3, Fig. 11)

Naviculopsis contricta (Schulz) Stradner (Pl. 5, Fig. 2)

Naviculopsis foliacea Deflandre

Naviculopsis lata (Deflandre) Frenguelli (Pl. 5, Fig. 9)

Naviculopsis trispinosa (Schulz) Gleser (Pl. 3, Figs. 12, 13)

Paramesocena circulus subsp. apiculata (Lemmermann)

(Pl. 4, Fig. 5)

Paramesocena circulus (Ehrenberg) subsp. circulus

Septenmesocena apiculata (Schulz) Bachmann

Actiniscus pentasterias Ehrenberg

Cinctactiniscus? sp. in Locker and Martini, 1986b (Pl. 3, Figs. 7, 8)

Foliactiniscus mirabilis Dumitrică

Ammodochium serotinum Locker and Martini

Ebriopsis crenulata Hovasse

Hermesinella conata (Deflandre) Locker and Martini

Parathranium clathratum (Ehrenberg) Deflandre

\section{ACKNOWLEDGMENTS}

I thank the Deutsche Forschungsgemeinschaft (Bonn) for supporting this study. Various discussions with S. Locker (Kiel) are gratefully acknowledged. Type specimens of new taxa are deposited in the Forschungsinstitut und Naturmuseum Senckenberg, Frankfurt am Main, Federal Republic of Germany, under Catalog Nos. SM.B 13826 and 13827.

\section{REFERENCES}

Barron, J., 1985. Late Eocene to Holocene diatom biostratigraphy of the equatorial Pacific Ocean, Deep Sea Drilling Project Leg 88. In Mayer, L., Theyer, F., et al., Init. Repts. DSDP, 88: Washington (U.S. Govt. Printing Office), 413-456. 
Bukry, D., 1976. Silicoflagellate and coccolith stratigraphy, southeastern Pacific Ocean, Deep Sea Drilling Project Leg 34. In Yeats, R. S., Hart, S. R., et al., Init. Repts. DSDP, 34: Washington (U.S. Govt. Printing Office), 715-726.

1982. Neogene silicoflagellates of the eastern equatorial Pacific, Deep Sea Drilling Project Hole 503A. In Prell, W. L., Gardner, J. V., et al., Init. Repts. DSDP, 68: Washington (U.S. Govt. Printing Office), 311-323.

1983. Upper Cenozoic silicoflagellates from offshore Ecuador, Deep Sea Drilling Project, Hole 504. In Cann., J. R., Langseth, M. G., Honnorez, J., von Herzen, R. P., White, S. M., et al., Init. Repts. DSDP, 69: Washington (U.S. Govt. Printing Office), 321-342.

Dumitrică, P., 1973a. Miocene and Quaternary silicoflagellates in sediments from the Mediterranean Sea. In Ryan, W.B.F., Hsü, U. J., et al., Init. Repts. DSDP, 13(Pt. 2): Washington (U.S. Govt. Printing Office), 902-933.

1973b. Paleocene, late Oligocene, and post-Oligocene silicoflagellates in southwestern Pacific sediments cored on DSDP Leg 21. In Burns, R. E., Andrews, J. E., et al., Init. Repts. DSDP, 21: Washington (U.S. Govt. Printing Office), 837-883.

Ehrenberg, C. G., 1846. Neue Untersuchungen über das kleinste Leben als geologisches Moment. Berichte Akad. Wiss. Berlin, 1845:53-87. , 1854. Mikrogeologie. Das Erden und Felsen schaffende Wirken des unsichtbar kleinen selbstständigen Lebens auf der Erde: Leipzig (Leopold Voss), 1-374.

Harland, W. B., Cox, A. V., Llewellyn, P. G., Pickton, C.A.G., Smith, A. G., and Walters, R., 1982. A Geologic Time Scale: Cambridge Earth Science Series (University Press), 1-131.

Ling, H. Y., and Takahashi, K., 1985. The silicoflagellate genus Octactis Schiller 1925: A synonym of the genus Distephanus. Micropaleontology, 31:76-81.

Locker, S., 1974. Revision der Silicoflagellaten aus der mikrogeologischen Sammlung von C. G. Ehrenberg. Eclog. Geol. Helvet., 67:631-646.

Locker, S., and Martini, E., 1986a. Silicoflagellates and some sponge spicules from the southwest Pacific, Deep Sea Drilling Project,
Leg 90. In Kennett, J. P., von der Borch, C. C., et al., Init. Repts. DSDP, 90: Washington (U.S. Govt. Printing Office), 887-924. 1986b. Ebridians and actiniscidians from the southwest Pacific. In Kennett, J. P., von der Borch, C. C., et al., Init. Repts. DSDP, 90: Washington (U.S. Govt. Printing Office), 939-951. 1989. Cenozoic silicoflagellates, ebridians, and actiniscidians from the Vøring Plateau (ODP Leg 104). In Eldholm, O., Thiede, J., et al., Proc. ODP, Sci. Results, 104: College Station, Texas (Ocean Drilling Program), 543-585.

Martini, E., 1971. Neogene silicoflagellates from the equatorial Pacific. In Winterer, E. L., Riedel, W. R., et al., Init. Repts. DSDP, 7(Pt. 2): Washington (U.S. Govt. Printing Office), 1695-1708. 1972. Silicoflagellate zones in the late Oligocene and early Miocene of Europe. Senckenbergiana lethaea, 53:119-122. , 1976. Neogene and Quaternary silicoflagellates from the central Pacific Ocean (DSDP Leg 33). In Schlanger, S. O., Jackson, E. D., et al., Init. Repts. DSDP, 33: Washington (U.S. Govt. Printing Office), 439-449.

Martini, E. and Müller, C., 1976. Eocene to Pleistocene silicoflagellates from the Norwegian-Greenland Sea (DSDP Leg 38). In Talwani, M., Udintsev, G., et al., Init. Repts. DSDP, 38: Washington (U.S. Govt. Printing Office), 857-895.

Perch-Nielsen, K., 1975. Late Cretaceous to Pleistocene silicoflagellates from the southern Southwest Pacific, DSDP, Leg 29. In Kennett, J. P., Houtz, R. E., et al., Init. Repts. DSDP, 29: Washington (U.S. Govt. Printing Office), 677-721.

Schiller, J., 1925. Die planktonischen Vegetationen des adriatischen Meeres. B. Chrysomonadina, Heterokontae, Cryptomonadina, Eugleninae, Volvocalea. 1. Systematischer Teil. Archiv Protistenkunde, 53:59-123.

Stöhr, E., 1880. Die Radiolarienfauna der Tripoli von Grotte, Provinz Girgenti in Sicilien. Palaeontographica, 26:69-124.

Date of initial receipt: 29 August 1988

Date of acceptance: 1 June 1989

Ms 112B-177 


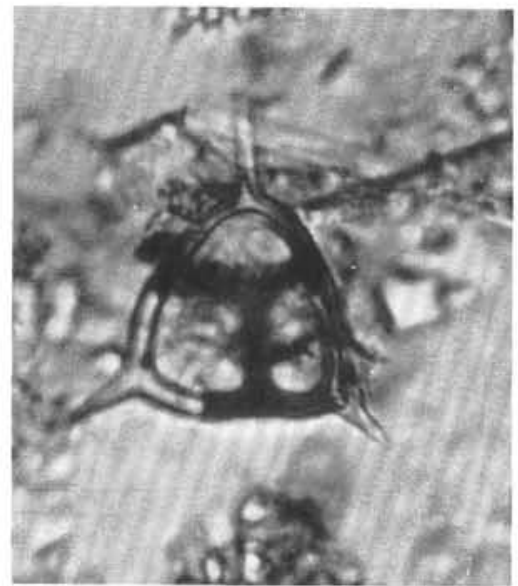

1

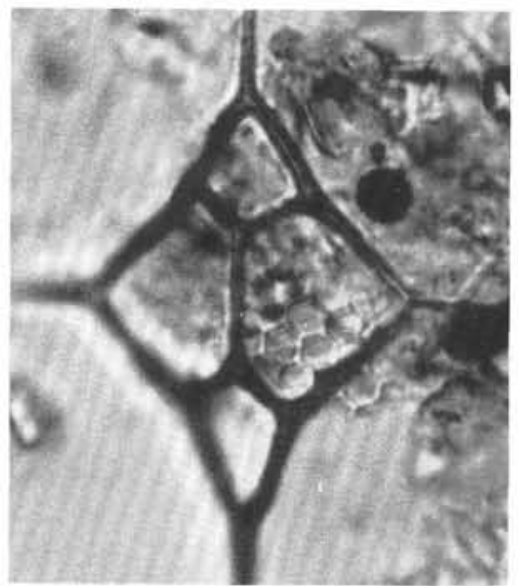

4

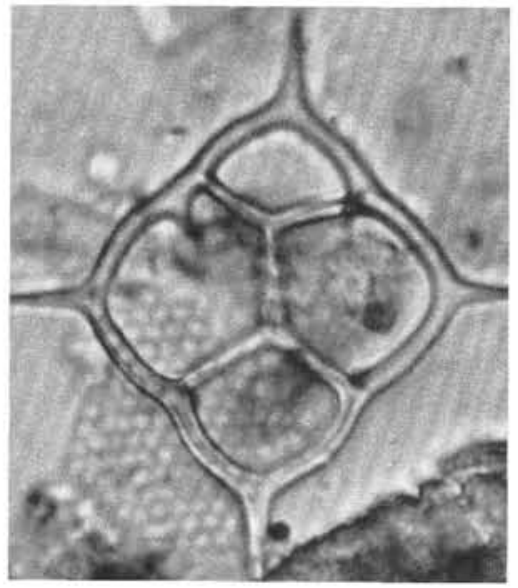

7

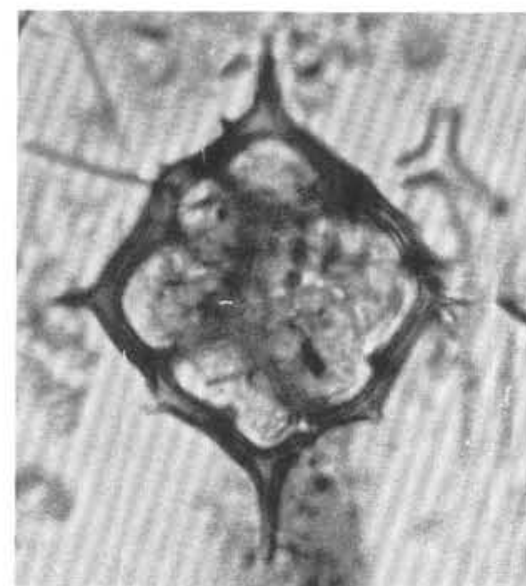

2

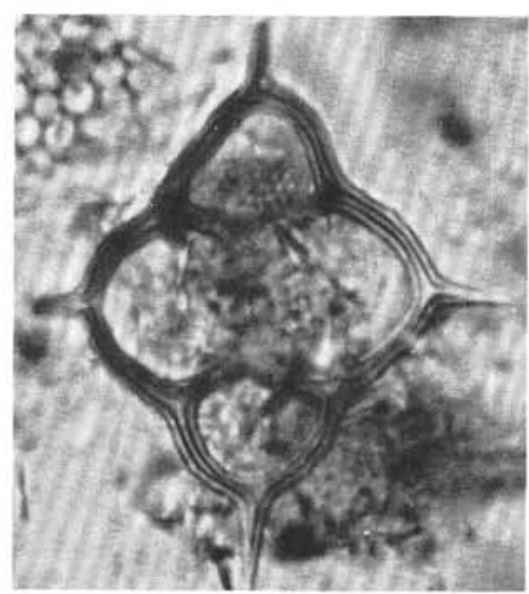

5

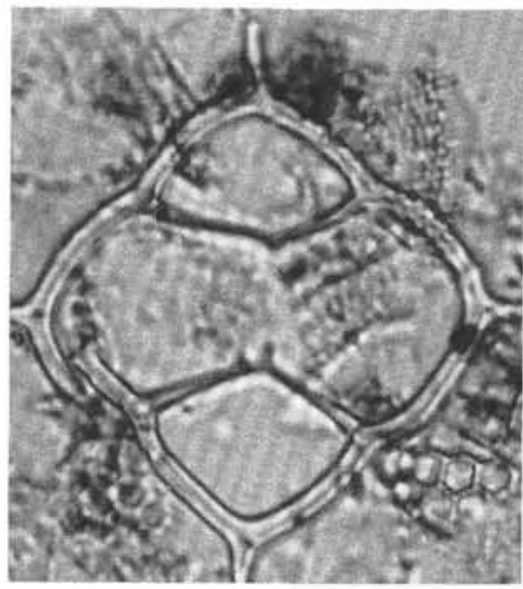

8

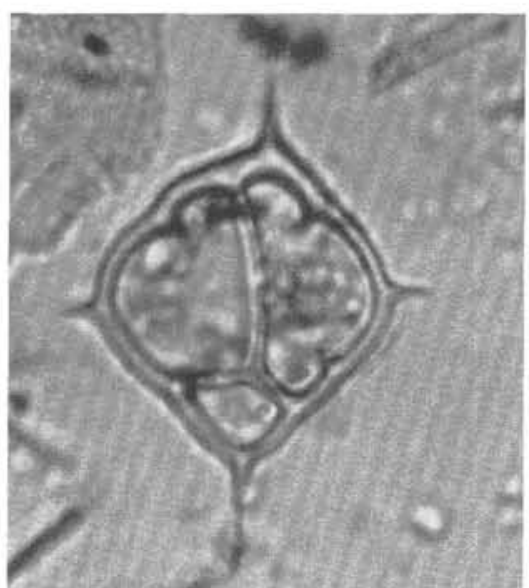

3

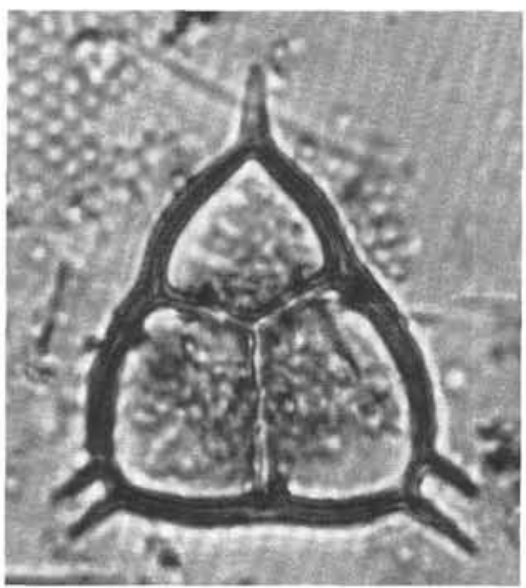

6

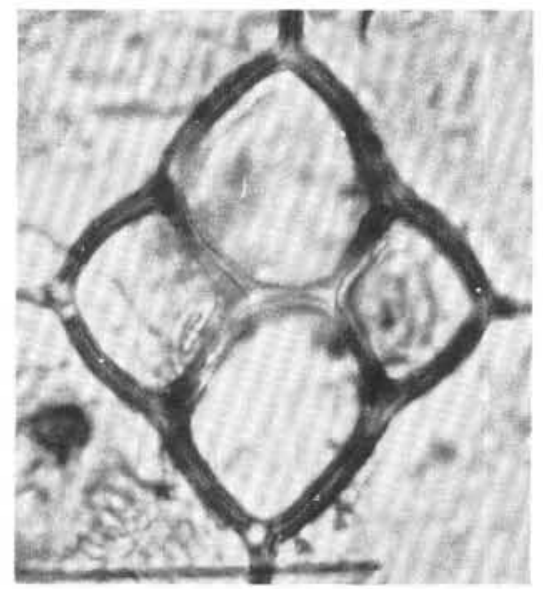

9

Plate 1. Neogene and Quaternary silicoflagellates (All specimens magnified 1180×). 1. Corbisema triacantha (Ehrenberg), displaced, Sample 112-688A-8X, CC, Quaternary. 2. Dictyocha messanensis subsp. aculeata (Lemmermann) f. aculeata, Sample 112-683A-7H, CC, Quaternary. 3. Dictyocha messanensis subsp. aculeata (Lemmermann) f. aculeata, aberrant specimen, Sample 112-688A-7H, CC, Quaternary. 4. Dictyocha concavata Dumutrică, displaced?, Sample 112-688A-6H, CC, Quaternary. 5. Dictyocha messanensis subsp. aspinosa (Bukry), Sample 112-688E-7R-7, $19 \mathrm{~cm}$, upper Miocene. 6. Dictyocha messanensis subsp. stapedia (Haeckel) f. stapedia, aberrant specimen, Sample 112-680A-1H, CC, Quaternary. 7. Dictyocha messanensis subsp. stapedia (Haeckel) f. stapedia, Sample 112-680A-1H, CC, Quaternary. 8. Dictyocha perlaevis subsp. delicata Bukry, Sample 112-688C-1R-1, $75 \mathrm{~cm}$, upper Pliocene/Pleistocene. 9. Dictyocha varia Locker, Sample 112-684A-7H-6, 80-81 cm, upper Miocene. 


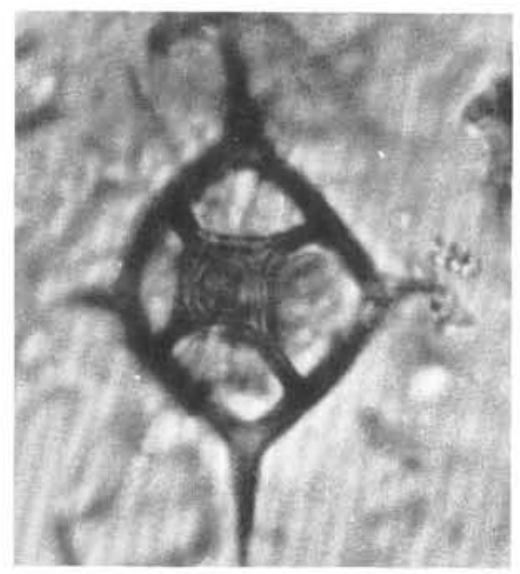

1

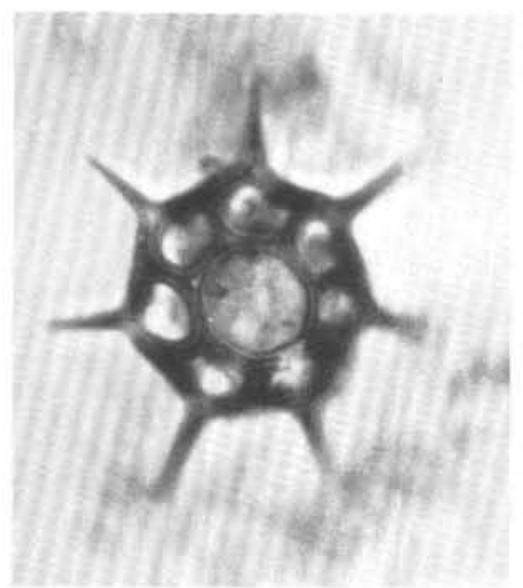

4

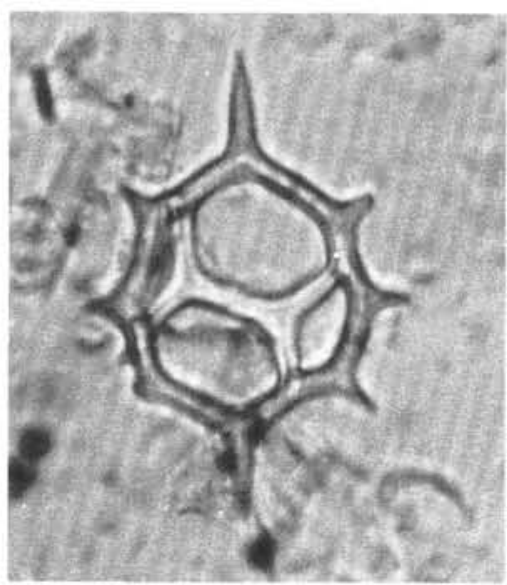

7

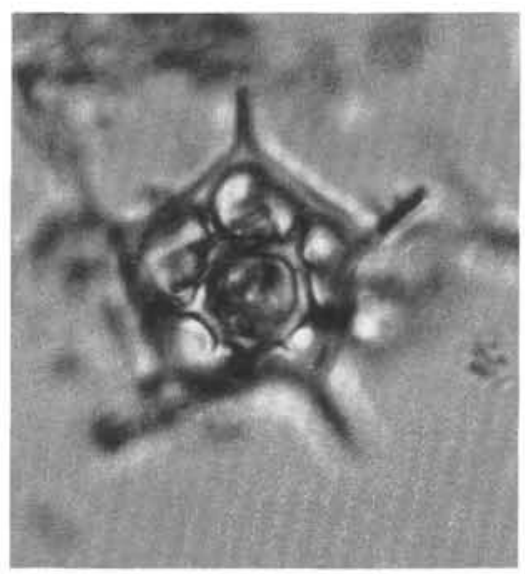

2

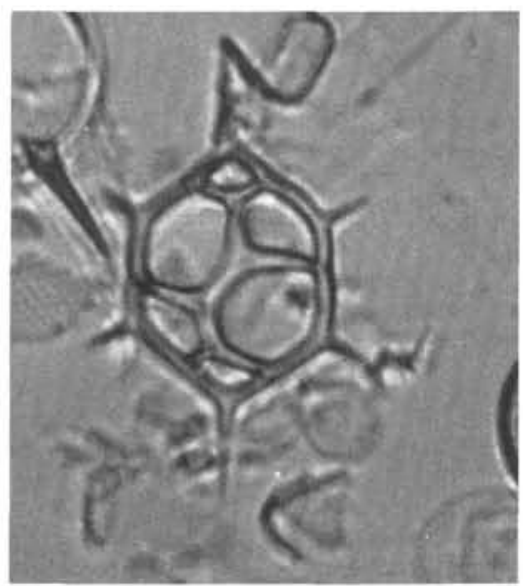

5

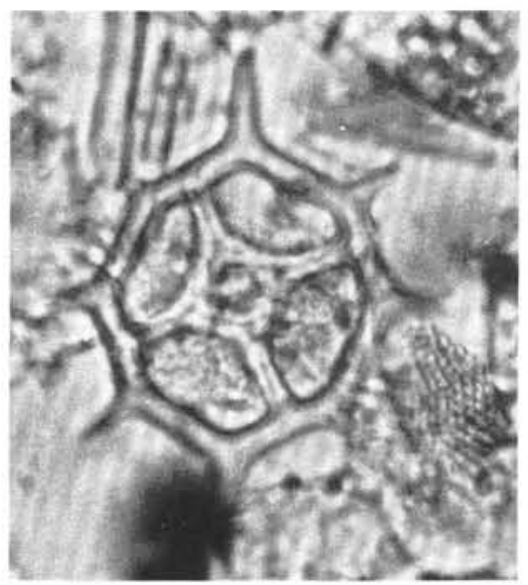

8

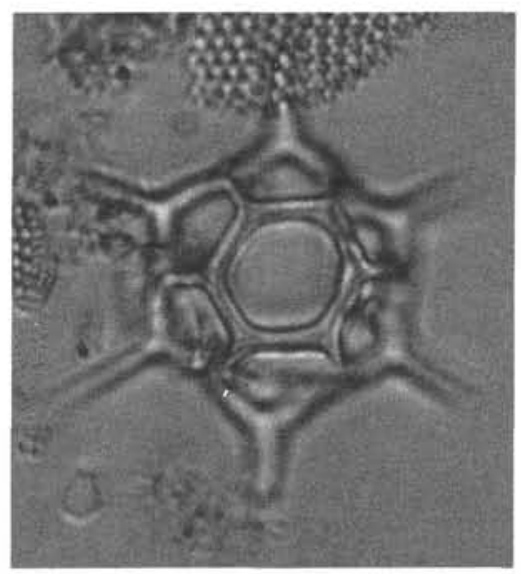

3

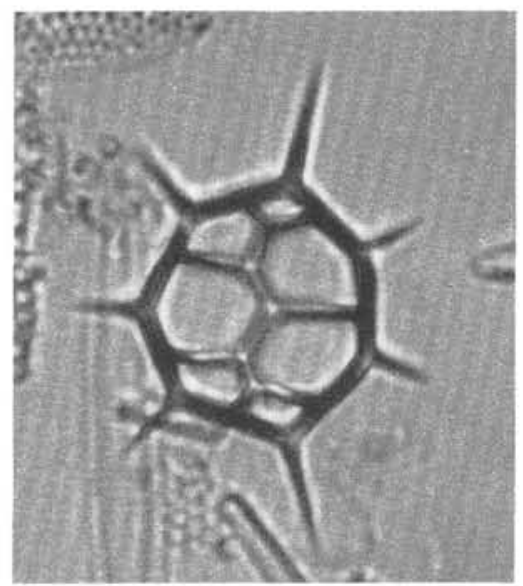

6

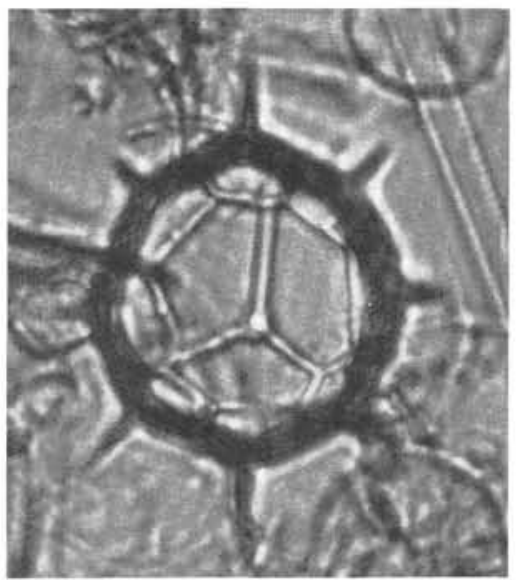

9

Plate 2. Neogene and Quaternary silicoflagellates (All specimens magnified 1180x). 1. Distephanus crux (Ehrenberg) subsp. crux, Sample 112-684A-7H-6, 80-81 cm, upper Miocene. 2. Distephanus speculum subsp. speculum $\mathrm{f}$. pentagonus (Lemmermann), Sample 112-688E-1R, CC, Quaternary. 3. Distephanus speculum (Ehrenberg) subsp. speculum f. speculum, Sample 112-679E-1X, CC, lower Pliocene. 4. Distephanus speculum subsp. speculum f. septenarius (Ehrenberg), Sample 112-688A-6H, CC, Quaternary. 5. Distephanus speculum subsp. speculum f. pseudofibula Schulz, Sample 112-679E-1X, CC, lower Pliocene. 6. Distephanus speculum subsp. speculum f. pseudoseptenarius $\mathrm{n} . \mathrm{f} .$, holotype SM.B 13827, Sample 112-679E-1X, CC, lower Pliocene. 7. Distephanus stauracanthus $\mathrm{f}$. octagonus (Tsumura), Sample 112-679D-25X, CC, upper Miocene. 8. Distephanus stauracanthus (Ehrenberg) f. stauracanthus, Sample 112-688E-18R, CC, middle Miocene, 9. Distephanus sp., Sample 112-679E-1X, CC, lower Pliocene. 


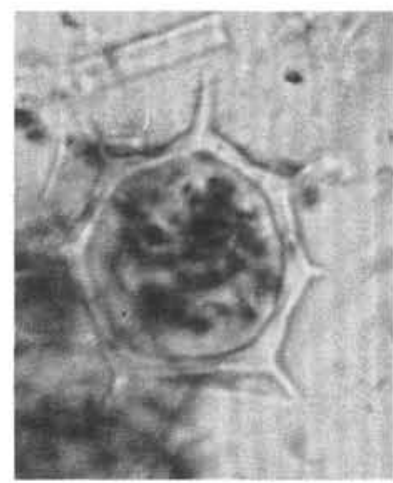

1

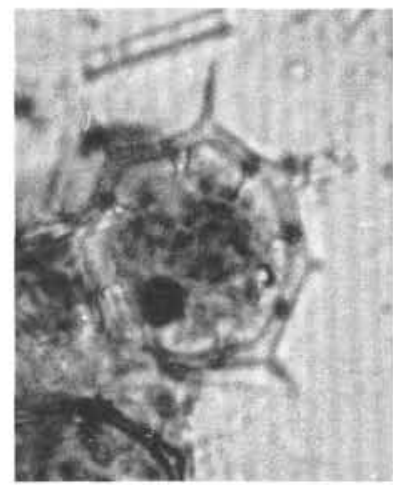

2

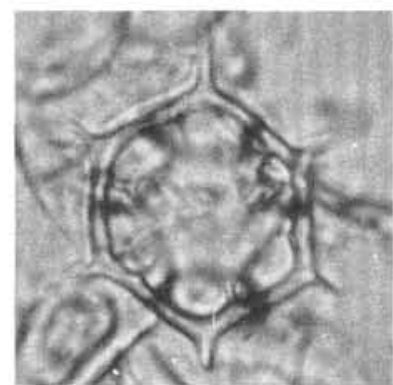

9

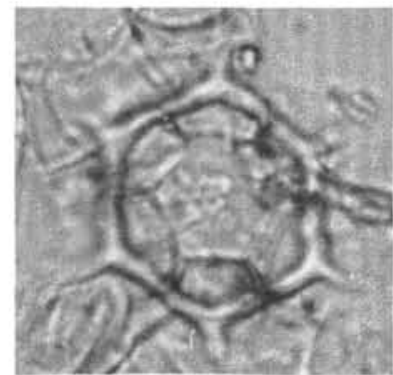

10

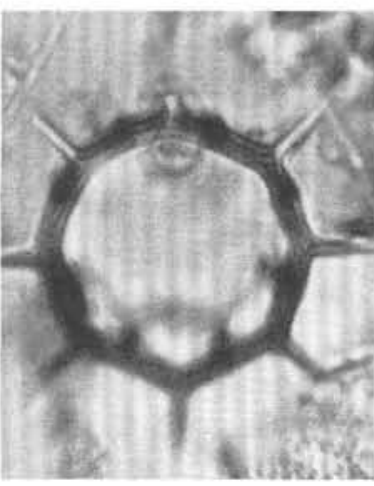

3

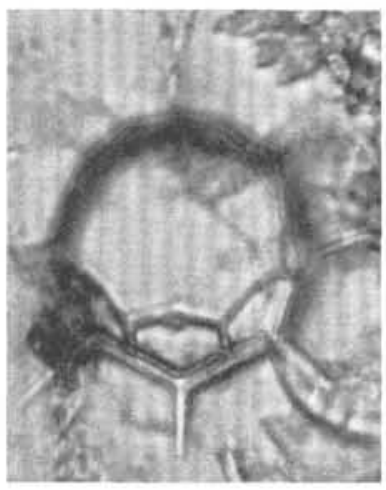

4

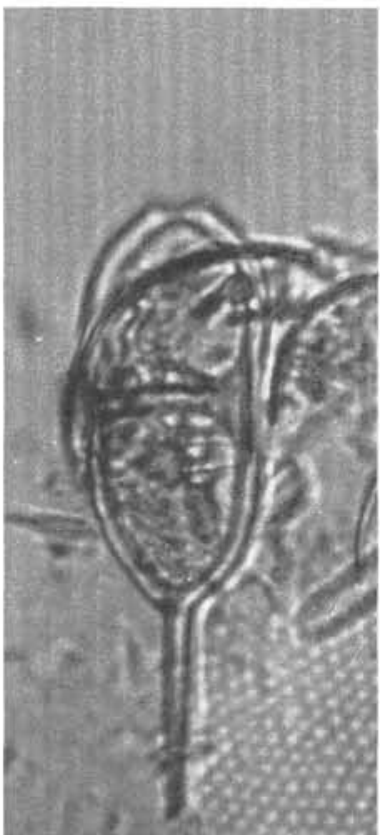

11

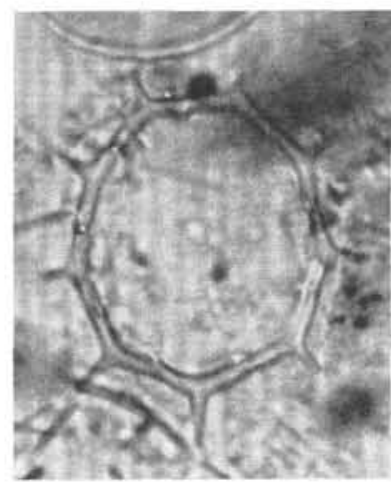

5

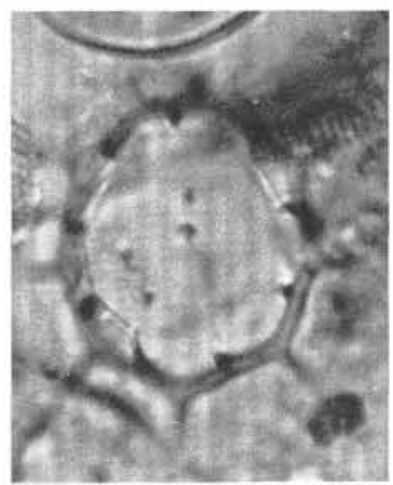

6

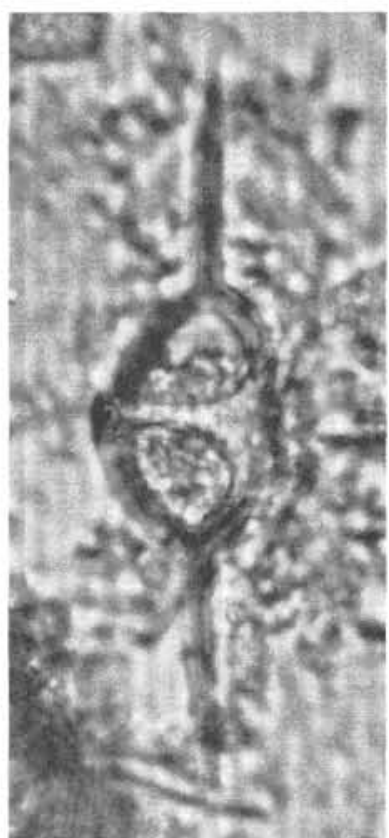

12

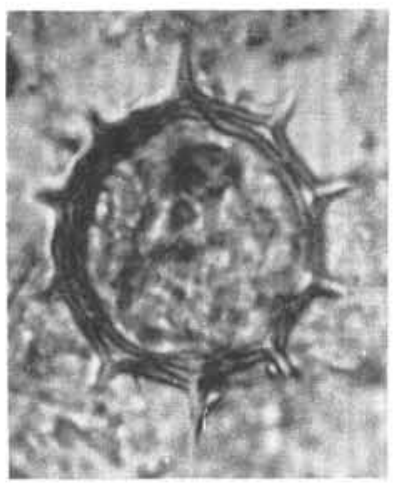

7

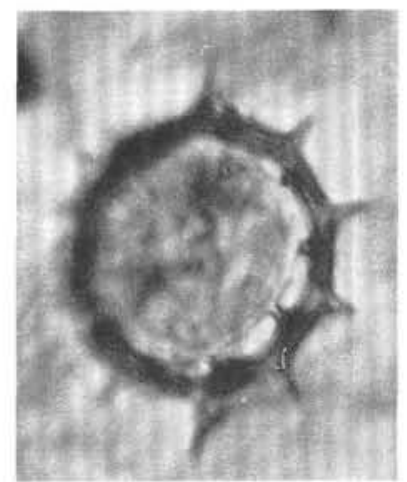

8

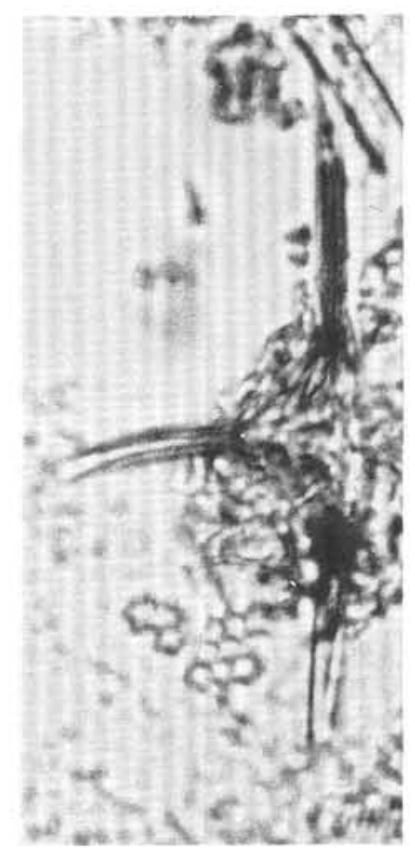

13

Plate 3. Neogene and Quaternary silicoflagellates (All specimens magnified 1180×). 1, 2. Distephanus bioctonarius $\mathrm{f}$. heptagonus (Ehrenberg), Sample 112-681A-10H-1, 27-28 cm, Quaternary. 3, 4. Distephanus bioctonarius (Ehrenberg) f. bioctonarius, Sample 112-679D-2H,CC, Quaternary. 5, 6. Distephanus bioctonarius f. binonarius (Ehrenberg), Sample 112-680A-6H, CC, Quaternary. 7, 8. Distephanus bioctonarius f. decimarius n.f., holotype SM.B 13826, Sample 112-681A-4H, CC, Quaternary. 9, 10. Distephanus speculum subsp. tenuis Bukry, Sample 112-679D-2H, CC, Quaternary. 11. Naviculopsis biapiculata (Lemmermann), displaced, Sample 112-688A-23X, CC, Quaternary. 12, 13. Naviculopsis trispinosa (Schulz), two different specimens, Sample 112-688E-25R-1, $141 \mathrm{~cm}$, lower Miocene. 


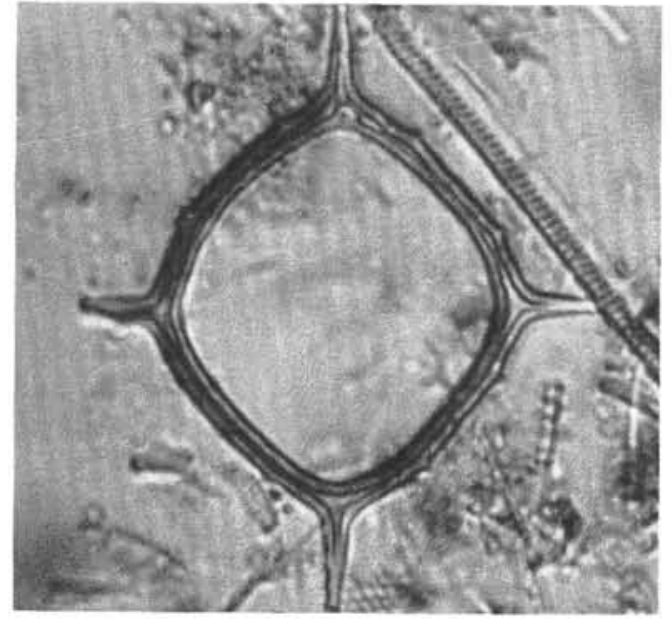

1

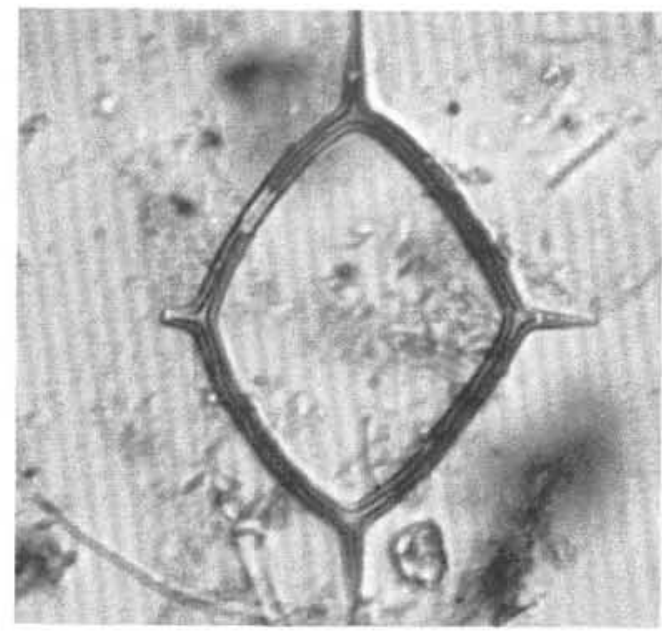

3

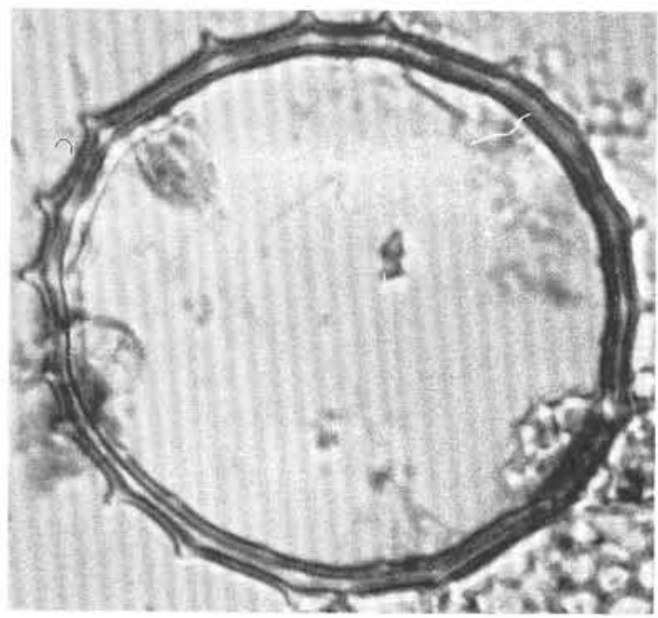

5

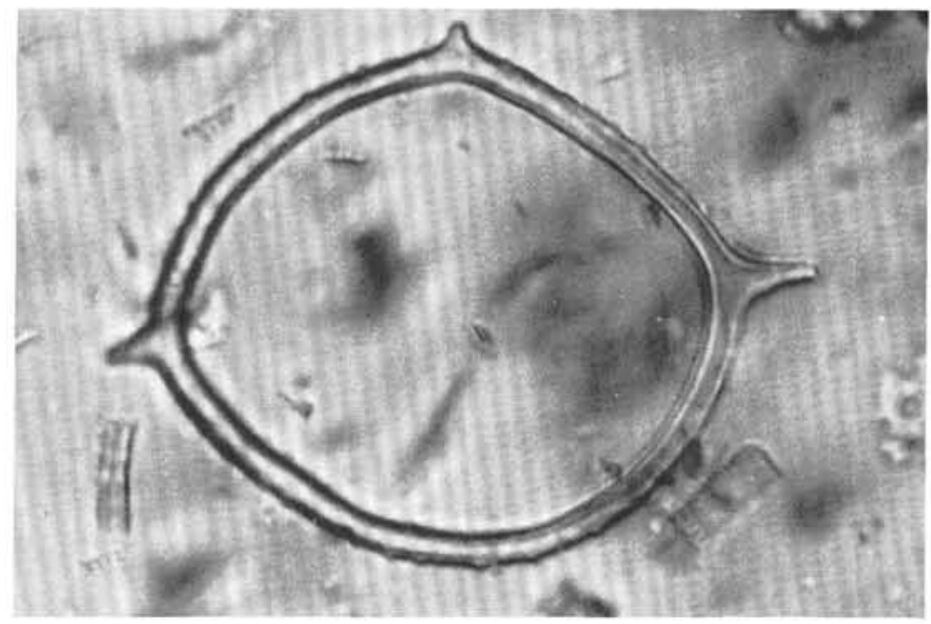

2

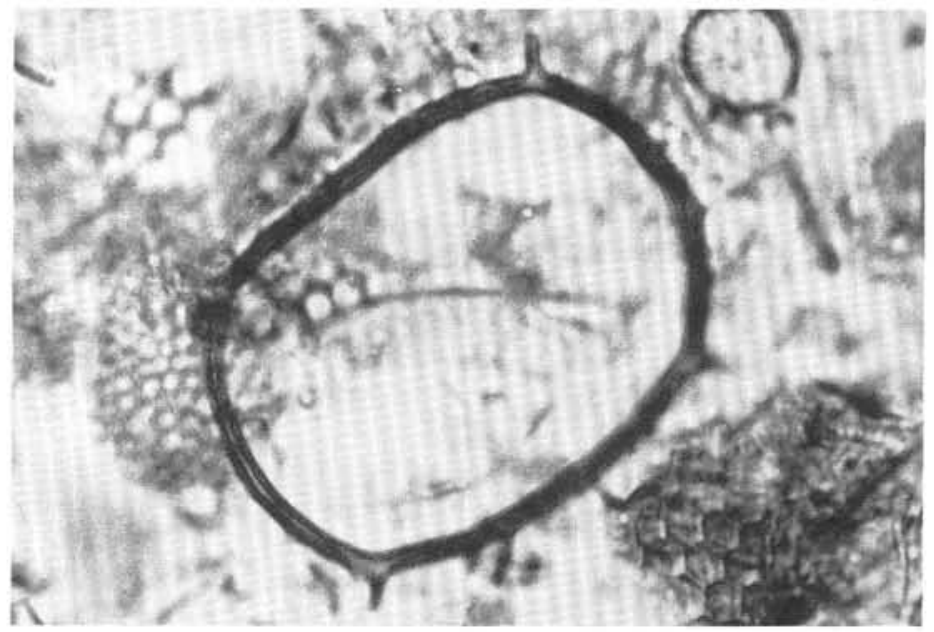

4

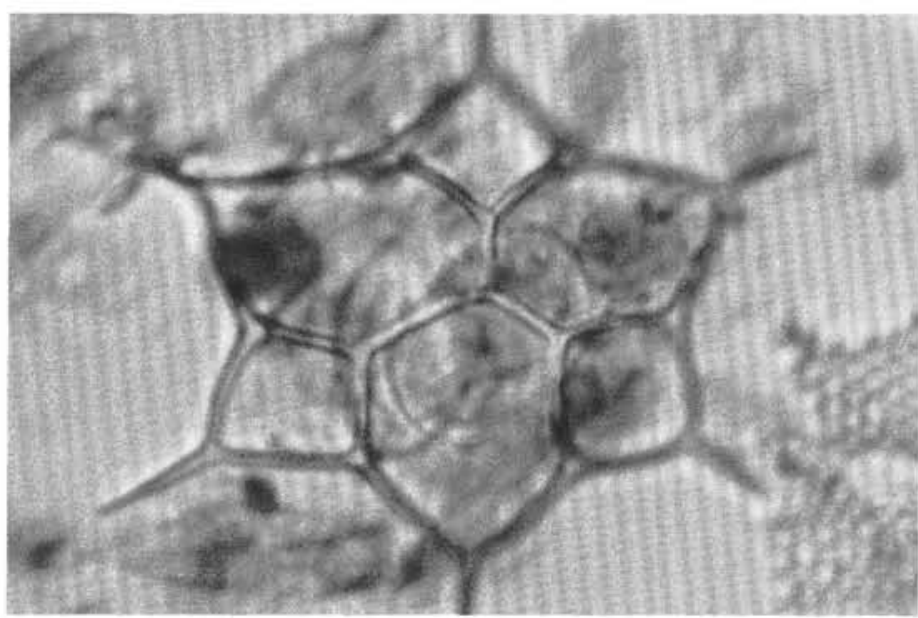

6

Plate 4. Neogene and Quaternary silicoflagellates (All specimens magnified 1180 $\times$ ). 1, 3. Mesocena quadrangula Ehrenberg ex Haeckel, two different specimens, Sample 112-688A-18X, CC, Quaternary. 2. Mesocena diodon Ehrenberg, Sample 112-688E-14R, CC, middle Miocene. 4. Mesocena quadrangula Ehrenberg ex Haeckel, aberrant specimen, Sample 112-688E-2R, CC, Quaternary. 5. Paramesocena circulus (Ehrenberg) subsp. circulus, Sample 112-684A-3H-4, 103-104 cm, upper Pliocene. 6. Dictyocha sp., Sample 112-686A-9X, CC, Quaternary. 


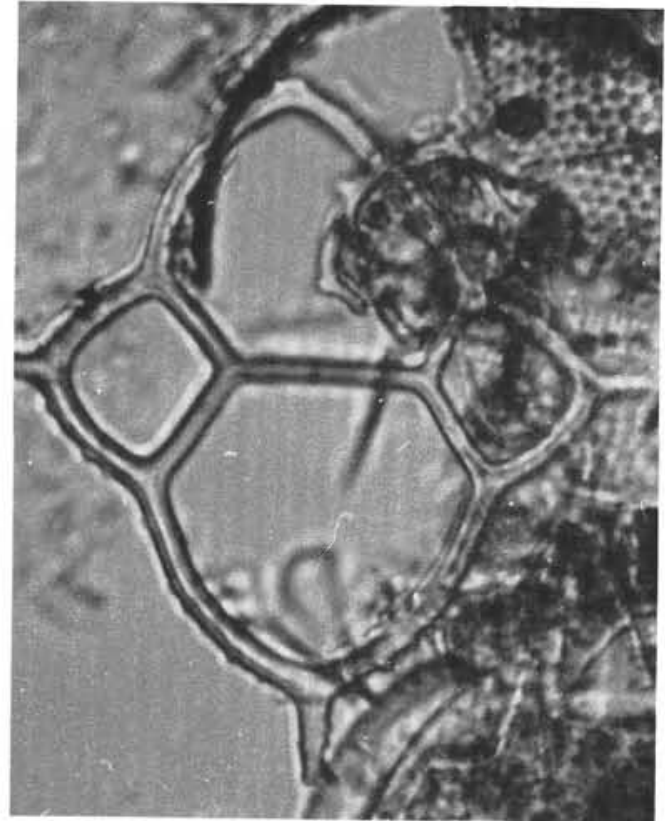

1

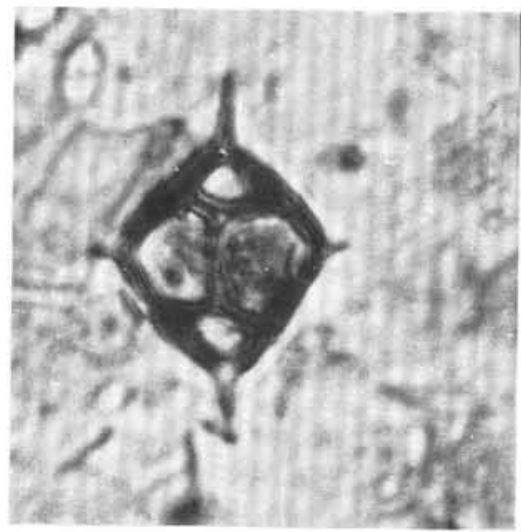

4

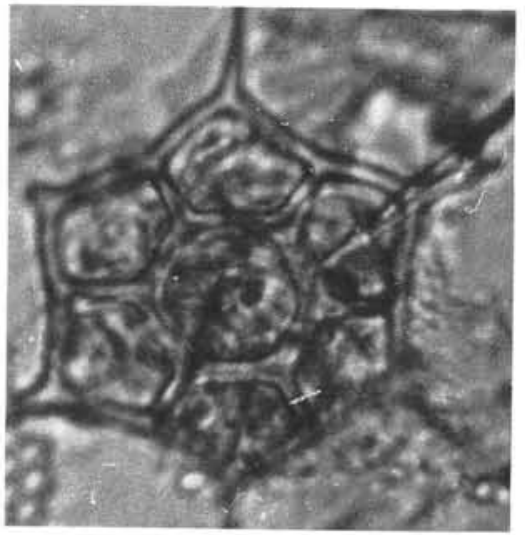

7

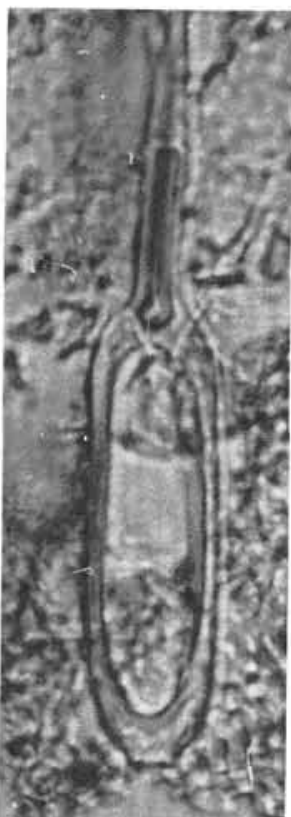

2

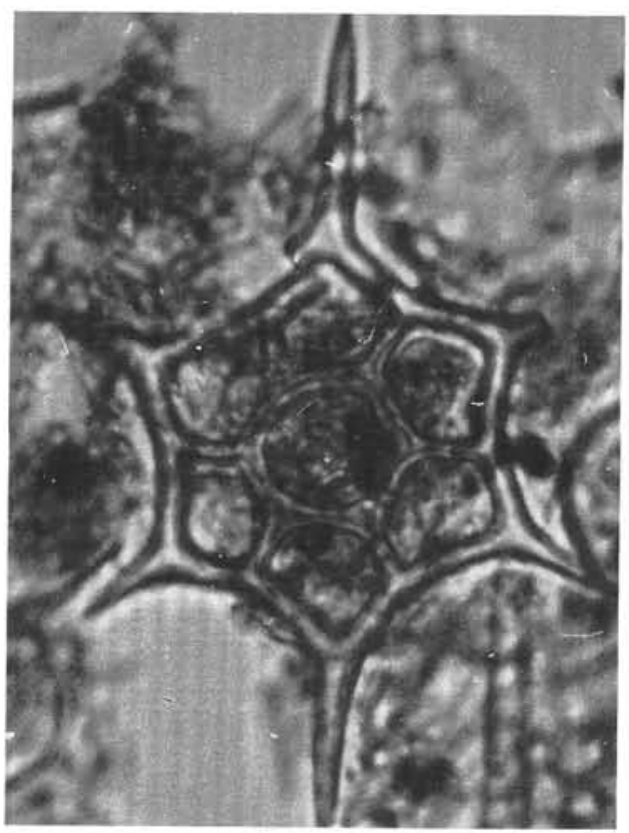

3

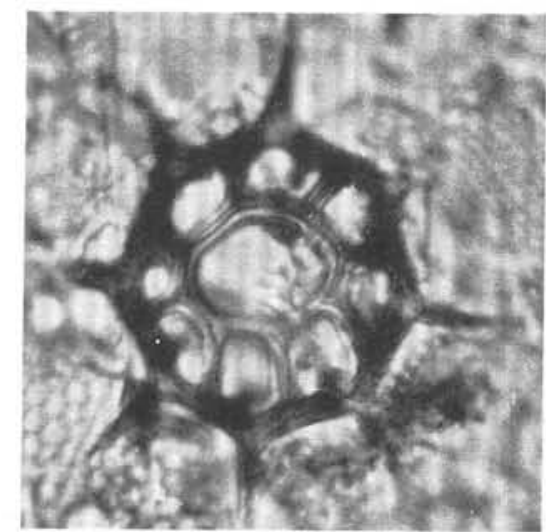

6

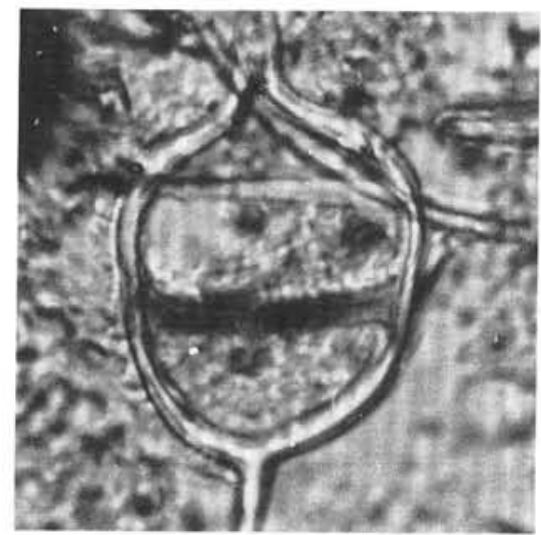

9

Plate 5. Neogene and Quaternary silicoflagellates (All specimens magnified 1180×). 1. Dictyocha fibula Ehrenberg subsp. fibula, Sample 112-682A-8X, CC, Pliocene. 2. Naviculopsis constricta (Schulz), Sample 112-685A-43X, CC, displaced, upper Miocene. 3. Distephanus speculum subsp. giganteus Bukry f. giganteus, Sample 112-688A-20X, CC, displaced, Quaternary. 4. Dictyocha messanensis subsp. stapedia (Haeckel) f. stapedia, Sample 112-688A-16X, CC, Quaternary. 5. Dictyocha medusa Haeckel, Sample 112-685A-36X, CC, upper Miocene. 6. Distephanus speculum subsp. speculum f. octonarius (Ehrenberg), Sample 112-681A-5H-4, 118-119 cm, Quaternary. 7. Distephanus aculeatus (Ehrenberg) f. aculeatus, Sample 112-688A-3H, CC, displaced, Quaternary. 8. Distephanus ? sp., aberrant specimen, Sample 112-685A-28X, CC, displaced, upper Miocene. 9. Naviculopsis lata (Deflandre), Sample 112-685A-29X, CC, displaced, upper Miocene. 